\title{
:econ
}

Instituto de Economía

Facultad de Ciencias Económicas y de Administración

Universidad de la República - Uruguay

Land frontier expansion in settler economies (18301950): Was it a Ricardian process?

\section{Henry Willebald}

Javier Juambeltz

ISSN: 1510-9305

ISSN: $1688-5090$ 
First versions of this paper were written as part of Willebald's PhD Thesis in Economic History at Universidad Carlos III, Madrid, Spain. He thanks Instituto Laureano Figuerola, Universidad Carlos III, for supporting his research as a $\mathrm{PhD}$ candidate. He is grateful for comments and suggestions by his supervisor, Leandro Prados de la Escosura, and his Thesis committee Collin Lewis, Branko Milanovic, Pablo Astorga, Alfonso Herranz and Isabel Sanz-Villaroya.

We thank comments and suggestions by the participants in the Workshop on "Comparative studies of the Southern Hemisphere in global economic history and development”, Research Institute for Development, Growth and Economics (RIDGE), Montevideo, Uruguay, March, 2015 -especially Prof. L. Bértola, G. Austin, E. Frankema and O. Licandro- and the XVIIth World Economic History Congress, Kyoto, Japan, July, 2015 -especially Prof. V. Pinilla and A. Booth. We thank the collaboration of Eugenia Riaño and Virginia Fernández in previous versions of this work and especially in the data analysis with GIS software. We are solely responsible for the remaining errors.

Forma de citación sugerida para este documento: Willebald, H., Juambeltz, J. (2016) "Land frontier expansion in settler economies (1830-1950): Was it a Ricardian process?”. Serie Documentos de Trabajo, DT 8/2016. Instituto de Economía, Facultad de Ciencias Económicas y Administración, Universidad de la República, Uruguay. 


\title{
Land frontier expansion in settler economies (1830- 1950): Was it a Ricardian process?
}

Henry Willebald* Javier Juambeltz\$

\begin{abstract}
Settler economies (Argentina, Australia, Canada, Chile, New Zealand, South Africa and Uruguay) benefited from the consequences of the Second Industrial Revolution as their temperate climate and fertile soils were especially suitable for the production of meat, wheat, wool and other commodities. The main domestic contribution to economic growth was the incorporation of "new" land, of variable quality, into the commercial and productive relationships of the first expansion of the world capitalism. Therefore our aim is to understand this process in the longrun (1830-1950) using the land frontier expansion as pivotal concept. Initially, we discuss the economic theories about the role of land in the economic activity and then, present an analytical model based on the classical Ricardian view to explain the land frontier expansion in terms of extensive and intensive margins in the agrarian production. Our empirical strategy uses a quantification method based on Geographic Information Systems (GIS) and we consider different agrarian land aptitudes and distances to centres of gravity to test our hypotheses. Our evidence supports the predominance of the extensive margin in the land frontier expansion of Argentina, Uruguay and New Zealand and the intensive margin in the two first economies and Chile but not in the other members of the "club".
\end{abstract}

Key words: settler economies, land frontier expansion, GIS, land quality.

JEL code: N5, N9, O13, Q24.

* Instituto de Economía, Universidad de la República, Montevideo, Uruguay

- Universidad del Trabajo del Uruguay - Ingeniería Tecnológica, Montevideo, Uruguay 


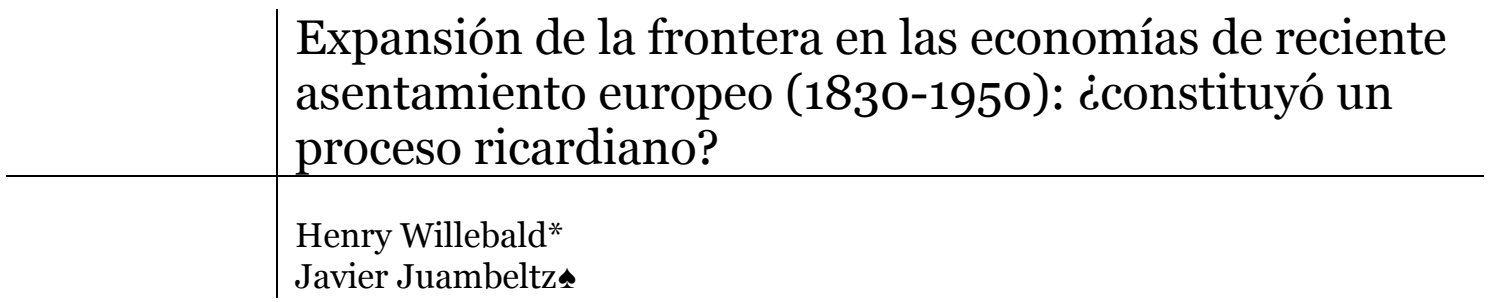

\section{Resumen}

Las economías de reciente asentamiento europeo (Argentina, Australia, Canadá, Chile, Nueva Zelanda, Sudáfrica y Uruguay) se beneficiaron de las consecuencias de la Segunda Revolución Industrial en tanto que su clima templado y fértiles tierras eran especialmente adecuados para la producción de carne, trigo, lana y otros bienes agrícolas. La principal contribución doméstica al crecimiento económico fue la incorporación de "nueva" tierra, de calidad variable, a las relaciones productivas y comerciales de la primera expansión del capitalismo mundial. Por lo tanto, el propósito de este estudio es comprender este proceso en el largo plazo (1830-1950) utilizando el concepto de expansión de la frontera como noción pivote en el análisis. Inicialmente, se discuten las teorías económicas acerca del papel de la tierra en la actividad económica y, entonces, se presenta un modelo analítico basado en la visión ricardiana clásica para explicar la expansión de la frontera en términos de los márgenes extensivo e intensivo en la producción agropecuaria. La estrategia empírica propuesta utiliza un método de cuantificación basado en los Sistemas de Información Geográfica (SIG) considerando diferentes aptitudes de la tierra y distancias a "centros de gravedad" en el territorio para testear las hipótesis de trabajo. La evidencia empírica constata que en los casos de Argentina, Uruguay y Nueva Zelanda se habría verificado un patrón de expansión de la frontera consistente con la idea de margen extensivo ricardiano, y que los dos primeros más Chile habrían presentado rasgos de expansión de la frontera de acuerdo con el margen intensivo (no así los restantes miembros del club).

Palabras clave: economías de reciente asentamiento europeo, expansión de la frontera, SIG, calidad de la tierra.

Código JEL: N5, N9, O13, Q24. 


\section{Introduction}

The expansion of the Atlantic economy since the mid $-19^{\text {th }}$ century until the First World War (WWI), the incorporation of new regions into the global economy and the formation of markets for goods and factors of production on a world scale are three of the main features of the First Globalization. The new settlement economies experienced an economic and social development and followed parallel paths (Duncan \& Fogarty, 1984) based on similar dynamic relations between waves of immigration, marginalization of native people, European capital inflows, land abundance, free labour, socially-useful political institutions and neo-European cultures (Lloyd \& Metzer, 2013). By the late $19^{\text {th }}$ century they were well integrated into the global economy and, in fact, the main settler areas in North America, southern South America, Australasia and the southern and northern regions of Africa became essential for the development of the global economy. These "temperate economies" include Argentina, Australia, Canada, Chile, New Zealand, South Africa, the US and Uruguay (Lewis 1983, p. 209), and Foreman-Peck (1995, p. 105) identifies this "club" with "the group of non-European countries which at the twentieth century can be classified as developed".

However, outcomes and development varied within the "club" and in recent literature these discrepancies have been explained by the institutional matrix that produces a set of organizations, rights and privileges; the stability of the structure of exchange relationships in political and economic markets; and a state that provides (or not) a set of political rules and an enforcement of rights. Studies contrast the experience of Latin America vs. North America and they propose explanations such as disorder vs. order in the economic change (North et al. 2000), the "South American way" (Landes 1998), cultural heritage (North 2003) and different ways of organizing a society identified with a "limited access order" (North et al. 2009). "In this characterization, the South American Southern Cone countries were the 'failure' in the settler club, with slower development paths and lower living standards" (Willebald 2007, p. 295).

In general, settler economies benefited from the consequences of the Second Industrial Revolution (railways, refrigeration, decreasing transport costs) as their temperate climate and fertile soils were especially suitable for the production of meat, wheat, wool and other commodities. Their natural resource endowments enabled them to take a fast track to expansion and, in the eve of the WWI, they reached levels of income per capita on a par with the richest economies. Their abundance of natural resources was understood as a "blessing" as these countries were able to participate in external trade with resources that were hitherto almost unexploited and for which European demand was dynamic and strong. 
The domestic contribution to economic growth was the incorporation of "new" land (of variable quality) into production, and this had consequences for the structural change, the evolution of income rates and the quantity and intensity of the use of factors of production. However, natural endowments are not the whole story. The expansion of the land frontier was related to the constitution of land ownership rights and, consequently, to the establishment of different land ownership systems and incentive mechanisms associated with them. These differences are one of the main factors in explaining why the income and distributive patterns in the settler economies changed in different ways (Álvarez et al. 2011; Álvarez \& Willebald 2013; Willebald 2011).

In this paper we focus on the incorporation of "new" natural resources (land) into the commercial and production relationships of the first expansion of the world capitalism and on understanding one of the main explicative factors of the economic evolution of settler economies (Argentina, Australia, Canada, Chile, New Zealand, South Africa and Uruguay) during a very long time that considers the mercantilist era of the 1830-186os, the First Globalization (1870-1910s) and the interwar period (1920s-1950). For this, we use the notion of "land frontier expansion". This old idea has followed a path with many transformations along the $20^{\text {th }}$ century, from the original "frontier hypothesis" of Frederick Turner in 1893 and its application for diverse countries and historical contexts during the first half of the century, to renewed conceptual views of the last decades in terms of cultural encounters and the construction of collective imaginaries. In recent years the interest in the frontier has reappeared following two paths. On the one hand, it complements the prolific line of research about the First Globalization which authors such as Williamson, O'Rourke and Taylor have actively promoted (Arroyo Abad 2013; Findlay 1995). On the other hand, it reacts and challenges this vision with the introduction of new insights that place the land frontier expansion as a pivotal concept that makes it possible to connect technological progress and institutional configuration (García-Jimeno \& Robinson 2011; Harley 2007). This conceptual revival offers new arguments to explain the comparative economic performance of settler economies during the First Globalization as a long-run process with roots in the previous period (we consider 1830-1870) and consequences in the following decades (we extend our analysis until the Second World War-WWII).

First, we present the concept of land frontier expansion and review the recent theoretical and empirical analysis in the literature (Section 1). Then, we discuss what the economic theory has proposed to understand the role of the land in the economic activity (fundamentally in terms of growth and income distribution) (Section 2). This review offers an overview of the concept from the initial notions where land played a central role (for the Physiocrats and Classical economists) to the current subsidiary position and the thematic specialization in fields as Agricultural Economics and Environmental Sciences. We use an analytical model that considers the classical Ricardian approach to understand the land frontier expansion in terms of the extensive and intensive margins in agriculture. After this, we discuss methods to measure the land frontier 
expansion considering the recent quantification efforts and the main shortcomings of these approaches (Section 3) and present our strategy based on the use of Geographic Information Systems (GIS). The application of these new tools in the Economic History field is a main contribution of this paper. After we explain the innovations introduced to deal with the restrictions of previous approaches -considering different land aptitudes (according to biomes and the idea of "potential vegetation") and distances to centres of gravity of the economy (Section 4) - we present our results. On the one hand, our evidence supports the extensive margin -in a Ricardian sense- in the land frontier expansion of Argentina, Uruguay and New Zealand but reject it for Canada, Australia and Chile where the geographical and historical conditions seem to determine a different pattern. The evidence for South Africa is not conclusive; it presents an intermediate situation. On the other hand, our evidence does not reject the intensive margin in the land frontier expansion for Argentina, Chile and Uruguay, but it does not support the hypothesis for Australasia and Canada (Section 5). Finally, we summarize the main findings and present new hypothesis.

\section{Is the land frontier expansion a classical concept that came back?}

\subsection{Interpretations and uses of a classical concept}

The most popular study about the importance of frontier expansion for economic development correspond to Frederick Jackson Turner, published in the Annual Report of the American Historical Association of 1893, where he postulated what is known as the "Turner thesis". This is the notion that the frontier attracted a particular type of person, and this was crucial in determining the development path of US society and in explaining why that country is exceptional. The frontier promoted individualism, social mobility, economic equality and freedom, and it was decisive to the development of democratic institutions in a process of "perennial rebirth" (Turner 1894).

This thesis enjoyed considerable popularity in the early $20^{\text {th }}$ century and the "notion of an aggressive pioneering national spirit nurtured by repeated exposure to primitive conditions became a means to national self-glorification" (Hofstadter 1970, 23; quoted in Furniss 2006, p. 26). Beginning in the 1920 s, this thesis came in for a wide range of remarkable empirical and theoretical criticisms like the fact that its overemphasis on a single determinant influence in the frontier environment meant ignoring other forces such as the class struggle, urbanization, religion, gender, ethnic heterogeneity, slavery and the growth of international capitalism (Furniss 2006). However, and probably due to the connection between the "Frontier Thesis" and American nationalism, Turner's ideas remained influential in economic, political and social thought for 
decades. It was not until the 1960 s and 1970 s that academic interest in the frontier revived and in the 1980 s a new approach emerged to definitively challenge the Turner's framework; this took the form of a "New Western History". In this new perspective the environment was seen not as a barrier to expansion but a factor that changed with human interaction. Many participants in the debate have even rejected the use of the term "frontier" because of its nationalist, racist and ethnocentric connotations. However, not all reactions were so extreme and some academics reintroduced the term into the analysis and defined the frontier as an area of cultural interaction. Similarly, Slotkin $(1985,1992)$ turned around the idea of the frontier myth as a narrative marked by the boundaries and the encounter of opposites (civilization and savagery, man and nature, good and evil). These encounters were described in terms of conflict and violence, and eventually resolved through domination and conquest (the subordination of indigenous peoples, nature and evil by the forces of progress, civilization and God). These ideas have constituted a fruitful line of research and have been applied in other regions in North America and in Australasia, South Africa, and Latin America (Hartz 1964; Winks 1971; Winks 1981).

According to Burt (1965), if Turner would have looked north when he wrote about the mass movement to the West, he might have discovered surprising evidence for his thesis in New France as "the westward movement was North American, not just American in the narrow sense of the word" (Mikesell 1960, p. 68). In any case, Turner's thesis remained of great interest throughout the first half of the $20^{\text {th }}$ century. In the 1920 s and 1930 s, it was popular in the Canadian historiography as an explanation of the national development and the comparison between the two North American "Wests". However, historians began to see more differences than similarities. Much of the credit for long-lasting interpretations of Canadian development belongs to Harold Innis, who suggested that the economic development of Canada should be approached from the standpoint of trade and staple production. In the second half of the $20^{\text {th }}$ century academics have acknowledged the power of the mythic West and its imagery. While some embrace it others attack it, but the thesis has remained part of the interpretation of national development. Some authors take note of the interlocking nature of American and Canadian westward expansion (Burt 1965) while others play down the similarities (Sharp 1955) and identify "several wests" in the overall expansion (Winks 1971). The historiography has been extensive and varied (Cross 1970), and in recent years subjects related to the imaginary (Francis 1992) and cultural issues have emerged (for a recent discussion, see Higham \& Thacker 2006). The long tradition of frontier studies in North America has comparable developments in other parts of the world.

The frontier is one of the most pervasive and evocative image underlying the creation of a national identity in Australia. According to Davis (2006), the most influential interpretation of the Turner view was that in Russel Ward's 1958 study, The Australian Legend, although previous contributions (Sharp 1955) of a Turner type had employed similar concepts and reached pessimistic conclusions about the supposed imperial utopia. Contemporary studies of the frontier follow one of two lines. On the one hand, there are interpretations of Turner's ideas, including 
considerations of several frontiers (Winks 1971, Winks 1981), in which New Zealand appears as a part of the process with particular characteristics (Coleman 1958) and they recognize a lasting impact on national identity in remote regions such as the Northern Territory (Loveday 1991). On the other hand, a variety of approaches have been introduced in the literature in which the frontier is considered as a discursive trope that settler society produces to reinforce the formation of civil society and cultural hegemony. A central point is the extent to which the nation-state "Australia" was founded on the violence and depredations of encounters in colonial times (Reynolds 1987, 2003).

Like North America, many parts of Latin America were conquered and settled by Europeans in a process that seems, at least on the surface, to be similar to what happened on the AngloAmerican frontier. However, except for Brazil and Argentina, Latin American academics have seldom seen the frontiers as important factors in the formation of national institutions and identities (Weber \& Rausch 1994). Various authors in the early $20^{\text {th }}$ century argued that the shortage of "free land"-which causes the rigidity of social systems in Hispanic America (Belaúnde 1923) - and the use of different institutions to deal with labour (such as missions and encomiendas) (Bolton 1917) make it difficult to apply the thesis. Apart from some exceptions like Aiton (1940), and Clementi (1986-1988)1- most Latin American historians consider their frontiers are unsuitable for a Turner-type analysis and seldom refer to Turner when they write about the frontier.

"Few influential Latin Americans regarded their frontiers as places of regeneration that went through a temporary 'return to primitive conditions' as they gave birth to individual liberty. Instead, most nineteenth century Latin American urbanites and intellectuals saw their frontiers as violent, brutal places that engendered despotism rather than democracy" (Weber \& Rausch 1994, xviii).

Notions in Latin America have changed progressively and the view emerged that it was not simply the physical environment that determined the impact of the frontiers on people, but the values that people brought to the physical environment. Hispanic colonizers wanted to incorporate those indigenous cultures into their own society, which is another reason why Latin American frontiers differed from those in North America (Zavala 1965). One of the more obvious consequences of this different "attitude" was "mestizaje" (racial mixture), a transculturation process that introduced distinctive characteristics not present in North America. According to Mikesell (1960), the Latin American "frontier of inclusion" contrasted sharply with the AngloAmerican "frontier of exclusion". This pattern changed in the $19^{\text {th }}$ century when the Latin

\footnotetext{
${ }^{1}$ It is quoted in Weber \& Rausch (1994, p. xvii, p. xxxv). 
American countries achieved political independence and needed to define political boundaries with active settlement that legitimated the new states.

The most important of these movements

“... was the wave of settlement which spread from the estuary of La Plata northward across Uruguay and westward across Argentina. This occupation of arable and grazing lands, previously the habitat of hunting Indians, by immigrants from Southern Europe; the construction of a railway network ... and the growth of the great cities of Buenos Aires, Rosario and Montevideo, are all in the classical tradition of the North America frontier" [...] "other neglected lands ranging from the arid pampa of Atacama to the rain-drenched forest south of Chile's Bío-Bío river attracted attention" (Butland 1966, p.94).

In the Atacama, the focus was a long-established form of mining, and in the forest there was a central European pattern of farming "cut-over" land that was slowly won from the Araucanians. At the same time, profits to be made from sub-Antarctic pastoralism stimulated European penetration in the cold lands of Tierra del Fuego, and similarly, irrigation in agriculture brought about a more intensive settlement pattern from the Río Negro through the Andean oases of Mendoza and Tucumán (Butland 1966, p.94).

\subsection{Land frontier and the role of endowments on economic performance}

In the 1970 s the notion of the frontier became less dominant (at least in its classical sense) and this opened the way for other conceptual frameworks to provide analytical support for the study of settler economies. In the recent literature about the expansion of the Atlantic economy during the $19^{\text {th }}$ century and the first decades of the $20^{\text {th }}$ century, the Stolper-Samuelson theorem from the Heckscher-Ohlin trade theory (H-O-S) is used to explain the performance of the New World.

1870-1913 was a real "golden age" for the settler economies. This expansion can be traced to the Industrial Revolution, a process that started in Britain in the second half of the $18^{\text {th }}$ century and in subsequent decades spread to other European countries, transmitting technological growth impulses from the core to peripheral regions. The formation of world commodity markets, mass migration and capital flows combined to make up one of the most important processes in the world economy in the last two centuries. Recent studies by Lindert, O'Rourke, Taylor and Williamson on globalization, growth, and inequality have opened up a fruitful line of research and generated multiple debates.

In every case the stimulus to development came from expanding markets in the world economy -usually expressed as rising prices- that led to an extension of the internal land frontier accompanied by considerable inflows of capital and immigrant labour. The new activities that arose were related to the production of primary exports, which generated additional demand for 
capital, labour and raw materials, and this demand was met, partly, from foreign sources. Therefore, the international and inter-regional mobility of factors were part of the story. The expansion of the frontier has played a secondary role in the modern historical analysis of settler economies, in spite of the fact that the main "domestic contribution" to economic growth was precisely the incorporation of "new" land into production. Only recently academics have seriously returned to the notion of frontier expansion.

Arroyo Abad (2013) presents a comparative view of some Latin American countries (Argentina, Mexico, Venezuela and Uruguay) during the $19^{\text {th }}$ century and considers a theoretical framework that connects up the effects on inequality of factor endowments and trade. This article includes an analysis of the effect on income distribution of labour movement, changing terms of trade and land expansion. Inequality depends critically on the relative scarcity of production factors and the distribution of their ownership. Land was not a fixed factor in these economies; at that time, large areas were incorporated into production and this enabled the settler economies to actively participate in international primary commodity markets. However, as populations grew, land became relatively less abundant and inequality increased. Findlay \& Lundahl (1994, 2001) and Findlay (1995) present a model that captures the structural pattern of the process with a combination of the "vent-for-surplus" and "staples" theories, and regard the endogenous land frontier as a main factor. In this conceptual framework, land frontier expansion is taken as the pivotal concept in an analysis of changes in relative prices, inflows of labour and capital, structural change and movements in income distribution. Neither of these analytical approaches is critical of the "mainstream" framework and they can be considered complementary visions to the general view (in the tradition of the H-O-S model) of the First Globalization and the development of the Atlantic economy. However, there have been other approaches that are more critical.

Recently, Knick Harley argues that applying the H-O-S approach means we should consider price convergence as a pivotal concept in the definition, identification and measurement of globalization. But, as globalization can be "defined as a shift from an economy where local supply and demand fluctuations dominated price fluctuations to one in which the economy became a price-taker to global forces [...] it need not depend on price convergence" (Harley 2007, pp. 240241). $19^{\text {th }}$ century globalization was a process in which peripheral economies were incorporated into the core of organized economic activity instead of "a regime switch to a more open trading relationship". We can consider their learning on how to best exploit their natural resources, their mobilization of capital and labour for production, their use and distribution, and the setting up of new institutional arrangements in different terms. Bértola et al. (2010) propose a framework compatible with this vision to explain the evolution of inequality in the South American Southern Cone (Argentina, Chile, Brazil and Uruguay) during the First Globalization. According to this analysis, the effect of globalization on inequality depended on the expansion of the frontier and on institutions persisting from colonial times, and this changed in old and new areas. Finally, in 
a recent article, García-Jimeno \& Robinson (2011) show renewed interest in the frontier. They analyze the classical "Frontier (or Turner) Thesis" for North, Central and South America from the mid-1 $9^{\text {th }}$ century to 2007. In this approach, the consequences of the existence of a frontier depend on the nature of the political institutions which came into being in the early independence period. When institutions placed few constraints on the executive, having a frontier was bad for development in terms of economic growth, income distribution and democracy.

From these perspectives, the focus on frontiers -that is, the incorporation of regions that originally were scarcely occupied and outside European economic influence- adds another viewpoint to the mainstream approach and helps to explain new questions in this field. Land frontier expansion is a pivotal concept that makes it possible to connect considerations about technological progress and institutional configuration in a different way. In this paper, we follow these concepts and consider land frontier expansion according to its contribution to economic performance as an endogenous process.

\section{What does the economic theory say about the role of the land?}

\subsection{A brief overview of economic though ${ }^{2}$}

The role of land, its conceptualization and its measurement in economic theory has changed considerably over time. For Physiocrats, the key economic activity was agriculture, due to its unique ability to yield a net product, which is a disposable surplus over costs. The net product introduced the idea of a surplus due to the bounty of nature, where the land is the only truly original or primary input. Toward the end of the $18^{\text {th }}$ century the focus on land as the only source of wealth could be represented in an aggregate production function of the form $Y=f(N)$, where $Y$ represents aggregate output and $N$ is the productive factor land. The characteristic agricultural bias of the Physiocrats is reflected not only in such a treatment of land but also in the stationary view of the economy. If the economy were organized according to the "natural order" it would rapidly attain a maximum level of output in accordance with the country's amount of arable land and with its state of technology. Both positions were ultimately abandoned by many writers within the tradition of Classical economics.

The first Classical economists wrote at the initial times of the Industrial Revolution, which coincided with the times of the rising of the industrialist class, and the beginning of the decline of the importance of landlords. The main research agenda was to establish the relationship between prices and inputs -labor, capital and land-, the earnings of the owners of each production factor (functional income distribution), as well as their contribution to economic growth. The importance of technological progress and capital for productivity was recognized, but many

${ }^{2}$ See an excellent review in Hubacek \& van den Bergh (2002). This subsection follows this review. 
Classical authors retained from the Physiocrats their special treatment of land. On the one hand, as fertile land was considered to be limited in supply, the classical economists believed that agricultural output was subject to diminishing returns. On the other hand, industrial machines, although lacking independent productivity, could be replicated and could be extended indefinitely, given suitable resources. The aggregate production function could be represented as $Y=f(N, K, L)$, where $K$ : capital, and $L$ : labour. This "classical triad" developed from the recognition of the three categories of participants in the economic process -landowner, workers, capitalists - associated with a triad of incomes -rent, wage, and profit- was the prevailing vision until the third quarter of the $19^{\text {th }}$ century.

With the further development of industrialism, capitalists and industrial workers became the dominant classes and the Economics shifted its attention to manufacturing. Important technological developments driving the Industrial Revolution might have also contributed to change the perception of land in the eyes of the British scholars, and a similar perception was contemporarily developed by American economists, although for different reasons. The American School tended to deny the classical law of diminishing returns and the Malthusian doctrine of population, since they seemed to contradict the facts in the "new world" because the existence of abundance of land, flexible ownership and tenure, and values related with competition and market. These facts influenced their perception about the form of the production function.

In the second half of the $19^{\text {th }}$ century, the methodology of Economics itself underwent substantial changes. It came increasingly under the influence of analytical mechanics and its maximization model, which led to shifts from production dynamics to an analysis of exchange value. The theory of production was replaced by a theory of allocation and prices. Physical realities disappeared from the theoretical view. Land, resources and energy became treated like any other factor of production or lost their status as unique production factors.

The distinguishing characteristics of the "neoclassical revolution" were probably shaped by the longevity of the industrial revolution, the pace of technological progress, shifts from food and fibre-based economies to mineral and fuel-based, and countries in the industrialized world that seemed to be almost independent of extractive industries. There were a number of controversies surrounding the concept of capital. The majority of writers still kept to the triad of factors and most economists continued defining capital as a particular category of goods, as flow rather than as a stock. Even though "physical" concepts still enjoyed greater popularity, nonphysical ones began to intrude. The trinity of factors was seen by some as an arbitrary grouping of homogeneous goods and some authors proposed to subsume all the factors under capital because land had no unique role in the production. Agricultural land had to be developed and maintained, just like any other capital good. Land transformed from being a primary input to both input and output of production. 
By the second half of the $2^{\text {th }}$ century land -or more generally environmental resourcescompletely disappeared from the production function and the shift from land and other natural inputs to capital and labour, and from physical to abstract measures of capital, was completed. The aggregated production function took the form $Y=f(K, L)$ and later developments reduced the production function to only one factor $Y=f(K)$, where no fundamental distinction between capital and labour is made and labour productivity is dependent on investment in training and education. Finally, for others authors, the central role corresponds to the generation and application of knowledge in the production and it is the "ultimate resource" where increasing returns rule over the production.

Parallel to an increasing reductionism in mainstream economic theory, neoclassical economists were readily available to extend their mathematical harmony designed for market transactions to questions of land and resource use. Empirical facts as well as theoretical considerations led to new specialization within mainstream economics. The classical concept of land as a factor of production was considered too restrictive since significant demand existed for the direct consumption of land. At the same time, the classical concept of land as encompassing all natural resources that is of economic significance was too broad to be useful for economic analysis. Consequently, land became subdivided among various sub-fields and many of the ideas developed by classical economists were incorporated into these. The common feature of these sub-fields is that they make land and environmental resources the central focus and base most of their methods on the assumptions of neoclassical economics. These sub-fields include agricultural economics, land economics, environmental and resource economics, and spatial (regional, urban and transport) economics.

\subsection{Our conceptual framework and analytical model}

Within this long conceptual evolution the idea of land frontier expansion is clearer represented through Classical Economics because the dynamics of the expansion and the incorporation of new land into the production are main concepts. The Ricardian Theory of Rent and the view of land presented by Johann von Thünen offer interesting insights into the matter.

In Ricardo's theory, there are two reasons for rent: unequal fertility and scarcity of land. Ricardo assumed a farm producing wheat by applying homogeneous labour to a fixed supply of land subject to diminishing returns. Land results an inexhaustible and non-reproducible factor, unalterably fixed in supply, completely specialized in the production of one crop, and homogeneous except for differences in fertility and location (Blaug 1990, pp. 79-82). These differences in fertility were the inspiration for his concept of the differential return because, "land is not unlimited in quantity and uniform in quality, and because in the progress of population, land of an inferior quality, or less advantageously situated, is called into cultivation, that rent is ever paid for the use of it." [Ricardo (1821 [2013]), Ch.2]. 
The second reason for rent was the scarcity of land. If land was homogeneous in quality, the limitations of supply would create only scarcity rents. The higher intensity in the production would exist even if all land were of equal fertility, as long as land was in scarce supply. In Ricardo's theory, labour and capital shift from one unit of land to another, but land itself never shifts between alternative uses. Land is supposed to be taken up freely when needed, not from another rent-paying alternative but from non-paying idleness. Resources are shifted between land and industry, never between different uses of land. As land has no alternative uses, rental payments do not affect the supply price of agricultural products. In Ricardo's words, the price of "corn is not high because a rent is paid, but rent is paid because corn is high".

In Ricardo's theory, the rent is the difference between the yield of a plot and that of the marginal plot (i.e., plots which yield just enough to pay for the costs incurred in the cultivation). The differential arises when inferior grades of land are cultivated. If the supply of superior grades of land was adequate it would not be necessary to cultivate inferior grades of land and rent would not arise. Rent arises because good quality of land is scarce. If the demand for food and raw materials further increases -due to population growth or the development of the economy-even after the whole of more fertile soil has been used farmers can adopt two possible courses of action. Firstly, they can use less fertile land for cultivation and, alternatively, they can cultivate the most fertile plot more intensively by applying additional doses of labour and capital. In the first case, Ricardo identifies the rent on extensive margin and, in the second, he identifies the rent on intensive margin (Murkherjee 2002).

A different view of the use of land was presented by Johann Heinrich von Thünen in 1826 . Whereas Malthus, Ricardo and others focused on different qualities of land, von Thünen used distance as the central concept. He was interested in the pattern of agricultural production around a central town in an isolated state, in a homogeneous featureless plain of equal fertility. He thought the principles that would determine the prices that farmers receive for their products, the rents that are earned and the patterns of land use. He developed a system of concentric circles, in which bulky or perishable goods are produced closer to the city and valuable or durable goods are imported from a further distance. In this central town the price of a product like grain is determined by the production and transportation costs from the most distant farms whose production is required to satisfy the town's demand. Since grain must sell at the same price irrespective of its location of production, ground rent is highest in the first concentric ring and decreases with distance. Von Thünen arrived at the same conclusions as Ricardo in observing that differences in the quality of soil will determine the land rent in the same manner as its proximity to the central town (Blaug 1990, pp. 614-617).

Therefore, when we analyze the land frontier expansion we should consider the triple impact of fertility, scarcity and location and how these factors influence the evolution of the incorporation 
of new land into the productive process of the settler club. But this conceptualization is not exempt of controversies. Ricardian Theory of rent has received several criticisms and one of them is the natural order of cultivation. Turner (1912) reviews the Carey's argument of Ricardian rent who states an inverse order:

"In the first settlement of a new country Carey thinks that the poorest tract, say No. 5 , will first be occupied, and with the growth of population and wealth 4, 3, 2, and 1 will successively come into cultivation. Carey's reasons are that the richer lands offer greater resistance than half-civilized men, or needy colonists, or the few new settlers in a virgin land with small capital and no organization, can overcome. The most fertile lands are covered with dense forests, among the most general difficulties are swamps or marshes, bogs and malaria. Through the growth of population, capital, and association such power over nature is acquired as will make possible the utilization of the most fertile soils" (Turner 1912, p. 655).

However, other authors disagree with this view.

"With this we may leave Mr. Carey's argument against the Ricardian doctrine of rent. The person who denies the truth of the Ricardian law in effect declares that men habitually rent highly fertile and comparatively infertile fields, rich corn lands and mountain pastures, at the same price; that men habitually rent lands near a market at the same price with lands the most distant from the market" (Walker 1883, p. 107). And this has very little sense.

In these terms, when Ricardo uses the words "best land" he means the land which is superior both in fertility and location and connects with the Von Thunen's thesis.

Regarding this last statement, we consider as the "best lands" those that combine conveniently fertility and location which we call land of high quality (land No 1 in Ricardian terminology) and set up the rest of the lands in terms of medium (No 2) and low (No 3) quality and we can represent the use of each one according to the following relationships:

$$
\begin{gathered}
\lambda_{h}=\frac{N_{h}}{N_{H}} \\
\lambda_{m}=\frac{N_{m}}{N_{M}}
\end{gathered}
$$


$\lambda_{l}=\frac{N_{l}}{N_{L}}$

Our land indexes corresponding to high, medium and low quality land are calculated as the proportion of the land occupied $\left(N_{h}, N_{m}\right.$, and $\left.N_{l}\right)$ of each type of land on the total area (endowment) of each quality $\left(N_{H}, N_{M}, N_{L}\right)$. Therefore,

$N_{h}+N_{m}+N_{l}=N \quad$ is the total occupied area and,

$N_{H}+N_{M}+N_{L}=N \quad$ is the available area (it potentially can be occupied).

We represent the shares of each type of land on total area as,

$$
w_{i}=\frac{N_{i}}{N}
$$

Where $w_{i}$ are fixed, known and represent the share of each type of land on endowment.

Our indicator of land frontier expansion $(\lambda)$ is the weighted sum of our land frontier expansion indexes,

$$
w_{H} \lambda_{h}+w_{M} \lambda_{m}+w_{L} \lambda_{l}=\lambda
$$

$$
\Lambda_{h}+\Lambda_{m}+\Lambda_{l}=\lambda
$$

This indicator tends to unity when the occupation on the land closes the frontier.

On the one hand, whether land frontier expansion associated with the extensive margin followed the "Ricardian Model" -in which the best land is cultivated first- our indicators would follow a pattern similar to that shown in Figure 1. Each type of land is incorporated until it is available and, at this point, landowners put in production the following quality.

To illustrate our point, we assume a country where a half of the land corresponds to high quality and the rest distributes equally between medium and low quality. We suppose a sustained and constant addition of land of 10 percentage points year by year. On the left axis, we represent the evolution of our land frontier expansion (LFE) indicators weighted by the corresponding land share -each one of the components of (7)'- (Figure 1.a). On the right axis, we represent the trajectory of the difference between high and medium+low quality components which we call our "difference quality index". 
However, this theoretical evolution does not result realistic. Usually, economies expand the frontier through different types of land simultaneously and we represent this fact in Figure 1.b. We assume that the land frontier expansion indicators corresponding to medium and low quality land are a half of that of high quality indicator in the initial moment. In the following years the increases of high, medium and low quality indicators are equivalent to 10, 5 and 2.5 percentage points (to respect the higher dynamism corresponding to high quality land).

Figure 1. Land frontier expansion and the Ricardian model

Panel (a): $w_{H}=1 / 2 ; w_{M}=w_{L}=1 / 4 ;$ LFE follows the theoretical Ricardian prediction

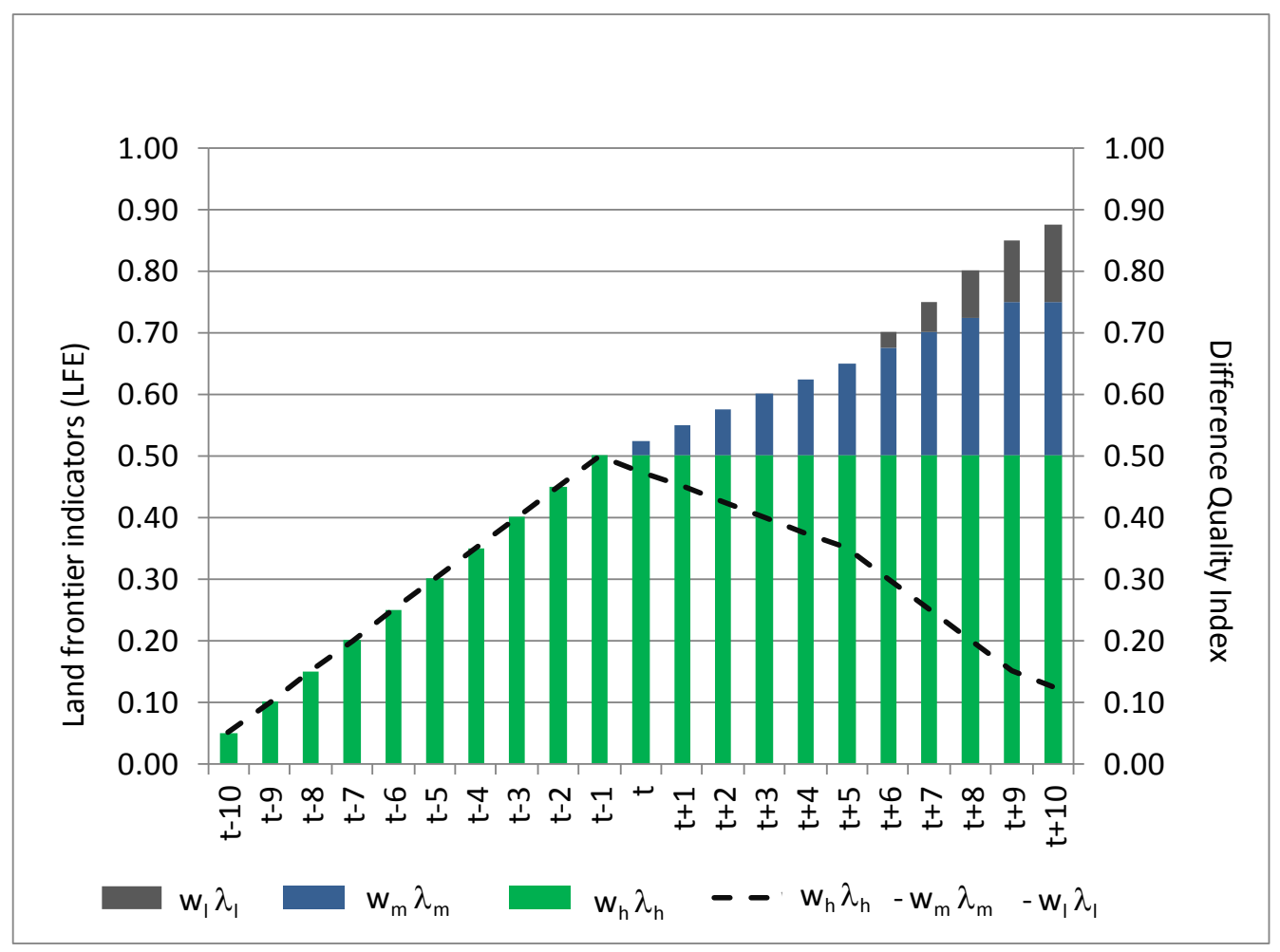


Panel (b): $w_{H}=1 / 2 ; w_{M}=w_{L}=1 / 4$; LFE follows a more "realistic" Ricardian prediction

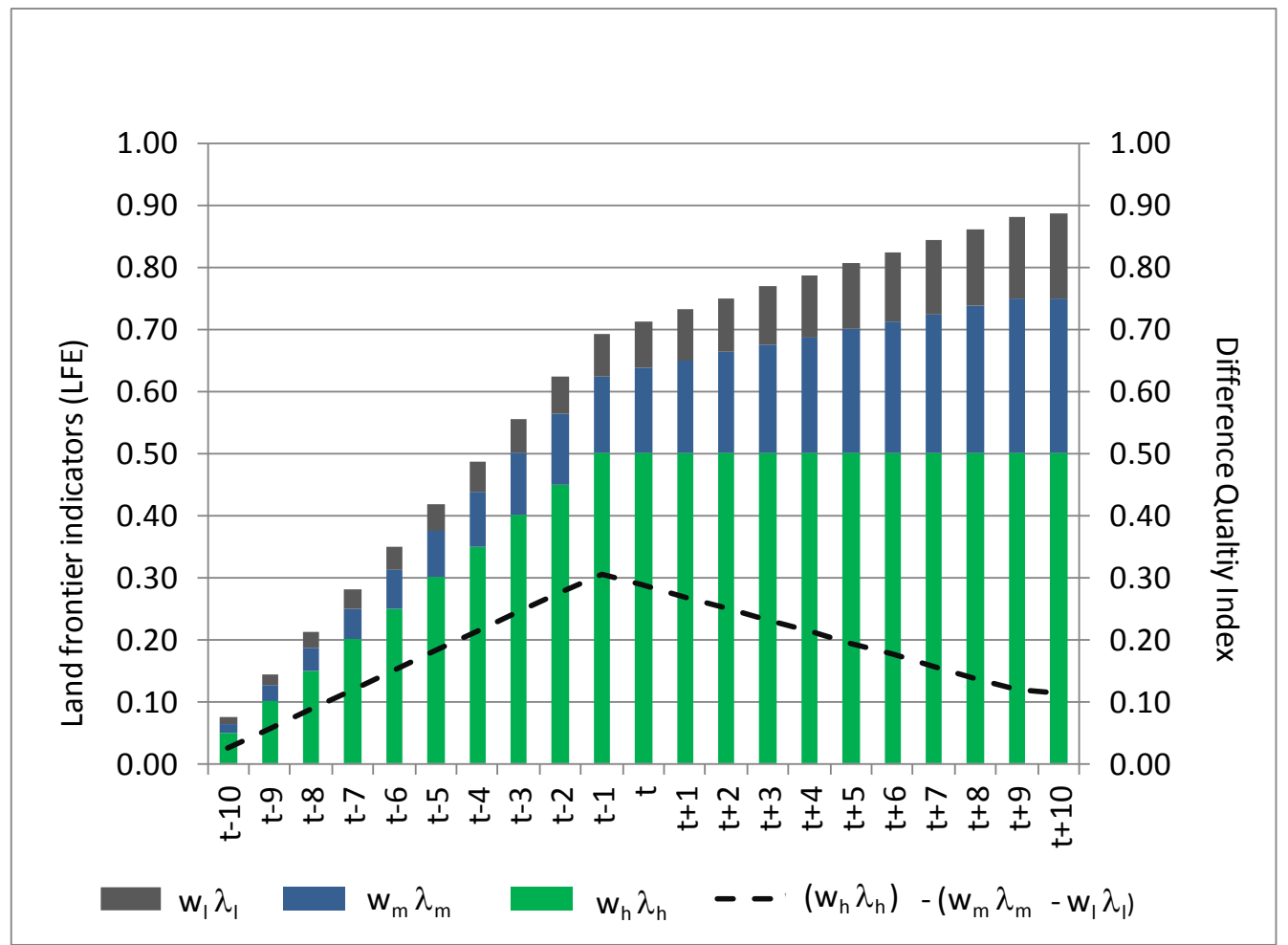

Therefore, a land frontier expansion according to the extensive margin shows an evolution where the high quality land predominates and this means that the difference quality index is positive. This indicator follows an increasing trend in the first stages of the land expansion and, when the high quality land begins being scarce, the index shows a decreasing trend. This is our first working hypothesis and we hope that each economy presents a specific path depending on its particular circumstances -historical, institutional and geographical- and productive patterns. We will not reject the hypothesis of extensive margin when the "order" by type of land follows Ricardian pattern which means that the land frontier expansion is led by high land quality in terms of volume and pace.

On the other hand, considering the intensive margin -that concerned with cultivating the most fertile plot more intensively by applying additional doses of production factors- we can assume as an indicator the relationship between the occupied lands and the population settled (as a proxy of labour) by type of land.

$\eta_{h}=\frac{N_{h}}{L_{h}}$ 
$\eta_{m}=\frac{N_{m}}{L_{m}}$

$\eta_{l}=\frac{N_{l}}{L_{l}}$

Where $L_{i}$ represent the population settled by type of land $(i=h, m, l)$ and $\eta_{i}$ the classical landlabour ratio used in the economic growth literature. When the intensive margin acts the indicator $\eta_{i}$ decreases because the quantity of labour per unit of land increases. Simultaneously, we expect more intensive labour doses in the best lands because they are capable to yield relatively higher incomes for the landowners than the worst lands. In other words, the same doses of labour in the same size of land of different quality would render more production in the higher quality land (diminishing returns appear later in best lands). If the intensive margin operated in the settler economies we can expect a decreasing relation between the ratio corresponding to high and the other quality (medium and low) or, in analytical terms:

$$
\frac{\partial \frac{\eta_{h}}{\eta_{m l}}}{\partial t} \leq 0
$$

Notice we contrast the land-labour ratio of high quality land and that corresponding to medium and low quality together. In Figure 2 we represent graphically this argument considering an initial moment where $\eta_{h}$ and $\eta_{m l}$ coincide and where the first decreases 20 per cent each period and the second only 5 per cent. By construction, the curve is concave and trends to zero in the long run. This is our second working hypothesis and we expect that each economy presents a specific path depending on the combination of endowments and timing of the expansion. 


\section{Figure 2. Land frontier expansion and the Ricardian model: intensive margin} $\eta_{h}=\eta_{m}$ in the initial moment.

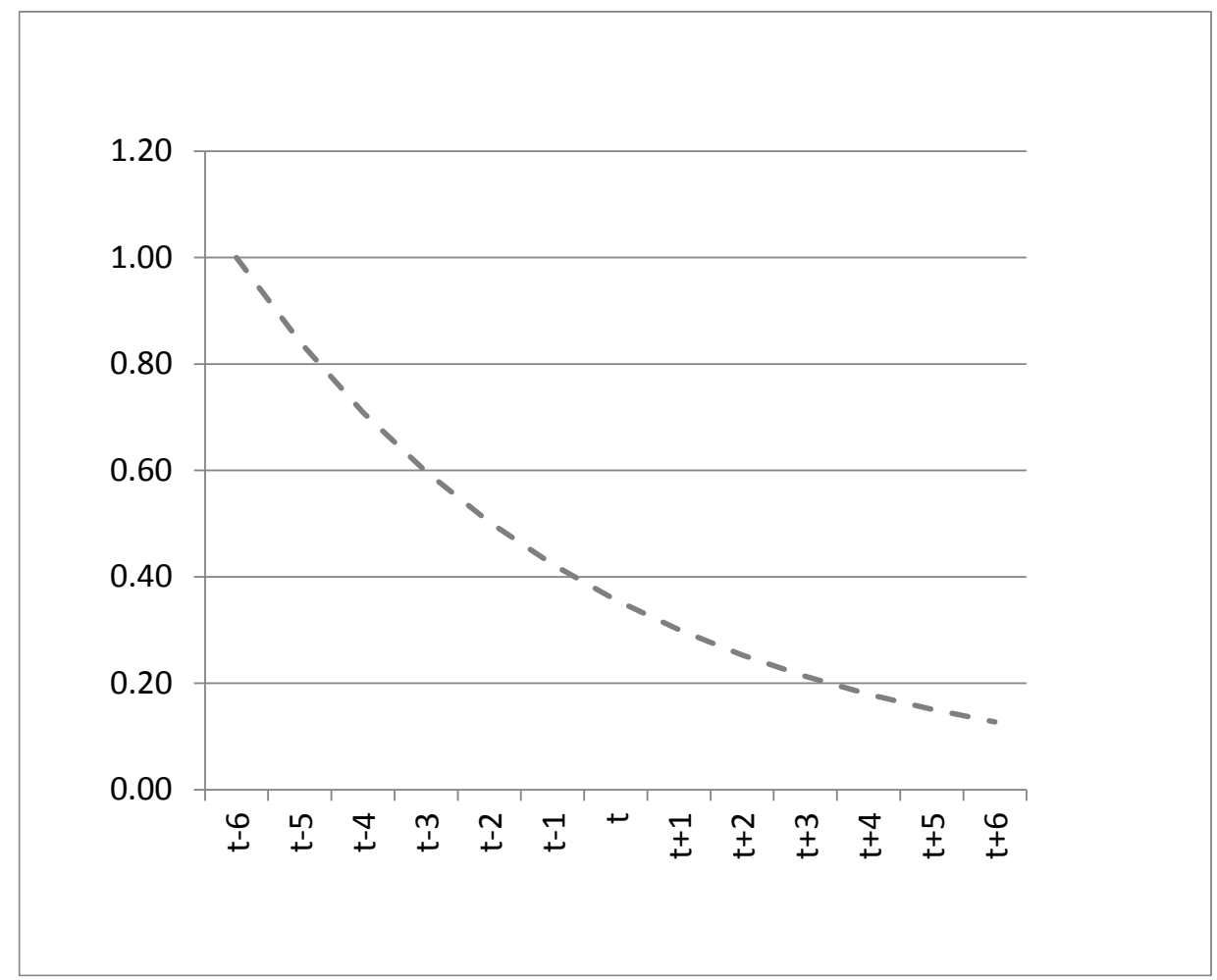

\section{Measuring land frontier expansion}

The literature about the frontier has been rather imprecise as to how the concept can be defined. It is hard to think of the frontier as a dichotomous condition because usually the boundaries are not clear-cut. In historical analysis, the "obvious" conditions to define a frontier are the presence of native communities not subject to state control, the absence of significant numbers of settlers and the inexistence of state institutions. However, there have been very few efforts to quantify the process. In this section we comment on some of these efforts and propose a new approach.

In the H-O-S framework approach, land frontier expansion is a concept introduced to consider changes in factor endowments, and the expansion itself is represented by the land/labour ratio.

"The land-labour ratio may decline in the long run as positive Malthusian forces associated with labour scarcity encourage early marriage, high fertility in marriage, and high child survival rates. Labour scarcity may also encourage a cross-border 
migration and thus an even greater and quicker decline in the land/labour ratio. Alternatively, high and rising wage-rental ratios may foster land settlement, a frontier experience that has received considerable theoretical and empirical attention in the literature." (Williamson 2002, p. 77).

Probably this "considerable theoretical and empirical attention" that Williamson mentions refers to the literature of the 1960s and 1970s that discussed the topic but we consider -as other scholars do- that the "frontier experience" is a concept that offers new insights. In this tradition, various studies have included both arable and pasture land in order to measure the expansion of occupied land against labour.

An example is Arroyo Abad (2013) who deals with additional questions. She provides a brief analysis of land frontier expansion considering the institutional and political conditions that characterized the incorporation of new land. She refers to the percentage of arable land transferred from public to private ownership when she considers land indicators. She, correctly, argues that "land was not a fixed factor of production in this part of the world because large tracts of land were brought into production at various times" (Arroyo Abad 2013, p. 44). Her paper concentrates on simulation exercises and concludes that the rise in inequality in Argentina and Uruguay until 1900 was explained by the impact of favourable terms of trade and international migration. However, the effect was dampened by significant land annexation because when more land comes under production through expansion of the frontier the marginal product of land falls and, in consequence, the relative land decreases.

García-Jimeno \& Robinson (2011) study the effects of the frontier on economic development but choose a different strategy. They estimate the proportion of land which was frontier (nonoccupied territory) in each independent country in the Americas in 1850. In their empirical work they use historical data about income per capita, democracy and inequality. They classify land with less than 2 people per square mile (0.7722 people per square kilometre) as frontier land. They work with various historical atlases of the regions and use Geographic Information Systems (GIS) to measure the area occupied. The threshold of "2 people per square mile" was employed by the US Census Bureau and was the criterion used by the US office that declared the country had a closed frontier in 1890. Therefore, the authors use the following index:

$$
F_{i, 1850}=1-\left(\frac{O_{i, 1850}}{T A_{i, \text { current }}}\right) \text {, where: } O_{i, 1850} \text { is the occupied area of country } i \text { in } 1850 . \text { Land is }
$$

occupied when the population density is greater than 2 people per square mile. $T A$ i,current is the total area of country $i$, current data.

The two types of indicators are different proxies to the conditions of relative endowments. Williamson's indicators emphasize the flow dimension and García Jimeno \& Robinson's approach concentrates on the stock dimension. The former are more suitable for dynamic analyses but 
hides differences in the relative factor levels. The latter is more useful for comparing endowment levels but have the disadvantage of being a static approach. In the neoclassical vision, the expansion of the frontier is important when it comes to conceptualizing movements in factor endowments, but beyond these considerations it is only of secondary interest. García Jimeno \& Robinson's approach focuses on the concept, and they propose a specific measurement using a new tool to study land frontier from a historical perspective. The connection between the expansion of the land frontier and settlement by colonizers is conceptually (and intuitively) correct and we follow the same strategy, but we have four observations to make about this approach.

First, and independently on the specific question we are dealing with, the choice of a threshold is always arbitrary. This objection is not against the number adopted (2 persons per square mile) but against the rigidity that this involves. We might consider several different thresholds to present land frontier expansion "intensities", and thus to open subsequently the possibility of incorporating the creation of markets and the economies of agglomeration more actively into the analysis. Second, the focus on just one period means we lose the dynamics of the process. In the expansion of the land frontier, movement is a fundamental dimension. By comparing different points in time we will be able to identify "shapes" of how occupied land expanded, and capture the possibility that non-frontier land might revert to being frontier again. Third, the use of today's administrative divisions does not incorporate the historical formation of institutional arrangements at different periods and therefore reduces the notion of "economic space" to "administrative space". Finally, the strategy of taking all of a country's national territory as a reference for "maximum frontier" is questionable. On the theoretical level we might assume that all the land can be occupied and exploited, but on the historical level it is arguable that for institutional and technical reasons there were regions that were not accessible. We discuss these arguments and present alternative ways.

\section{A proposal for approaching the land frontier expansion}

The starting point is to know how many inhabitants were settled in an area. We assume that the presence of a relatively high level of population is the best proxy for land incorporated into economic activity. Another approach would be to consider the setting up of institutions that establish property rights and state control over these regions which is matter of previous studies (Álvarez \& Willebald 2013; Willebald 2011). 


\subsection{How can we solve the shortcomings of the previous approach?}

Testing our hypotheses drives to pay attention to a couple of those shortcomings. First, we construct our indicator every 10-year between 1830 and 1950 to overcome the static perspective. Second, primary sources of the data consider current local administrative divisions as reference, but combined with natural conditions and the use of simulation models based on population density makes it possible to "paint the map" (to identify different regions in the territory) independently of local jurisdictions (see the description below). We illustrate our approach with a series of maps (Figure 2) showing the evolution of population counts in four large regions (Oceania, North America, Southern Cone of South America, and South Africa) for two year benchmarks $(1830,1950)$ and with ten ratings, from 0-10 inhabitants to more than 25,000 per cell. Georeferenced information represents data referred to spatial localization of the values of variables in cells of $69.4 \mathrm{~km}^{2}$ and colours represent different ranges.

Figure 2. Population settlement, 1830-1950

\section{Figure 2.a. References}

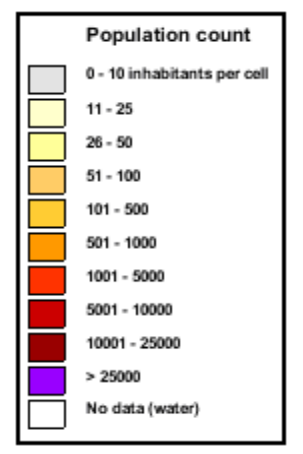

Figure 2.b. Oceania: Australia and New Zealand

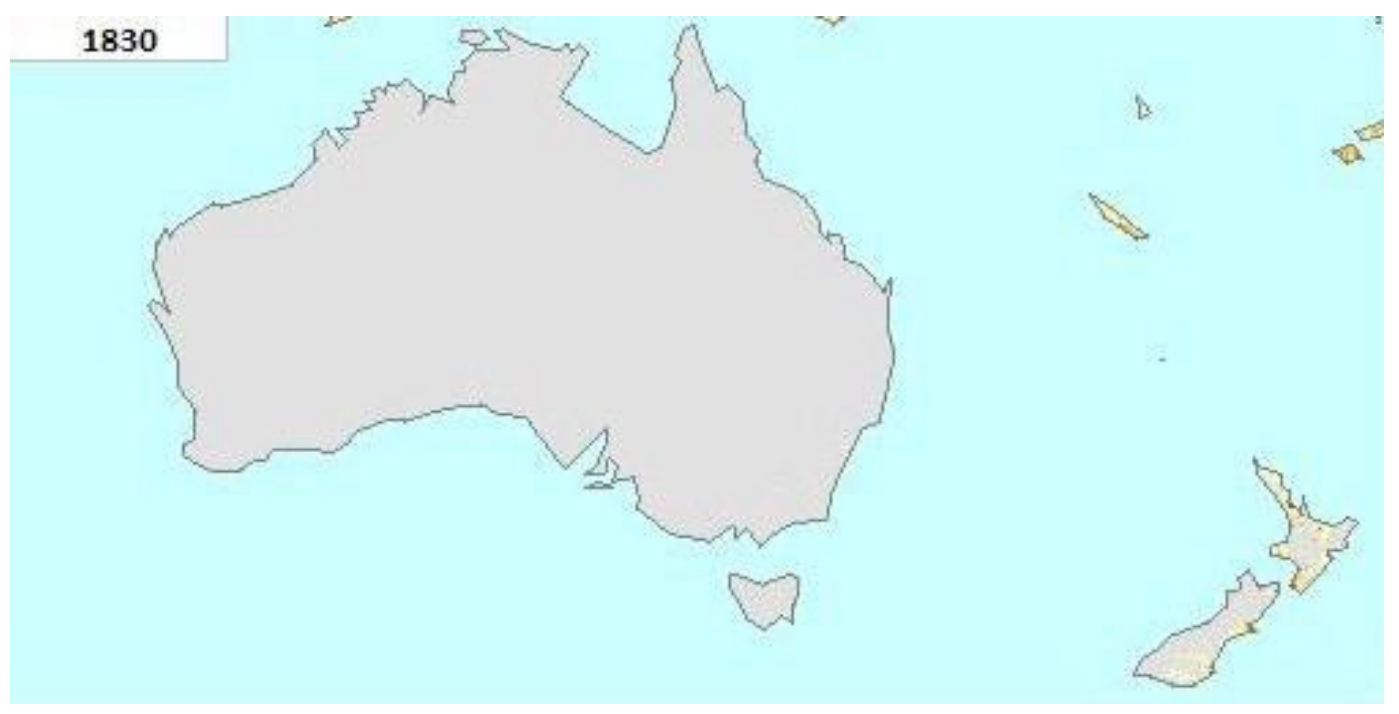




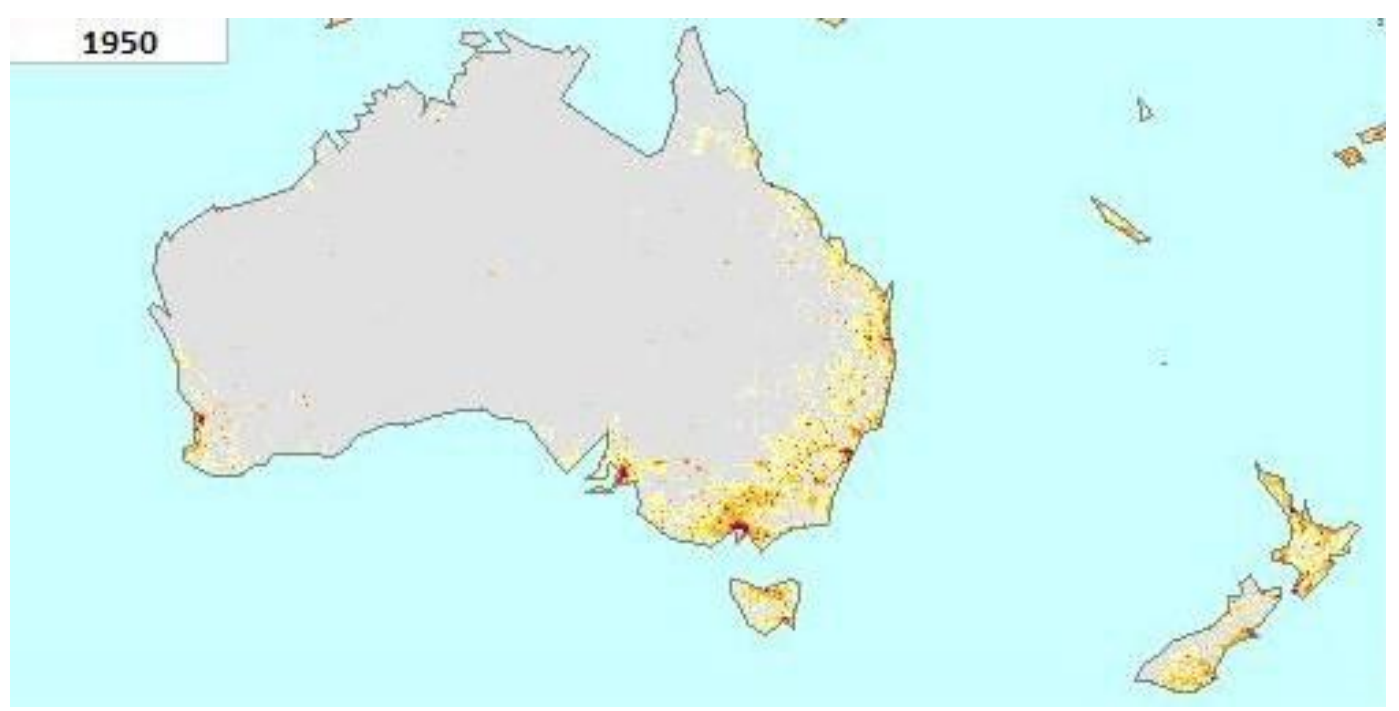

Figure 2.c. Africa: South Africa
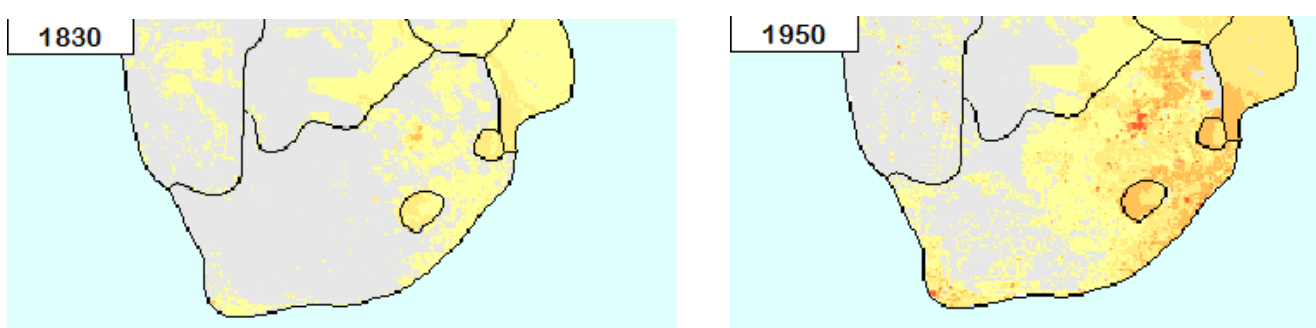
Figure 2.d. North America: Canada
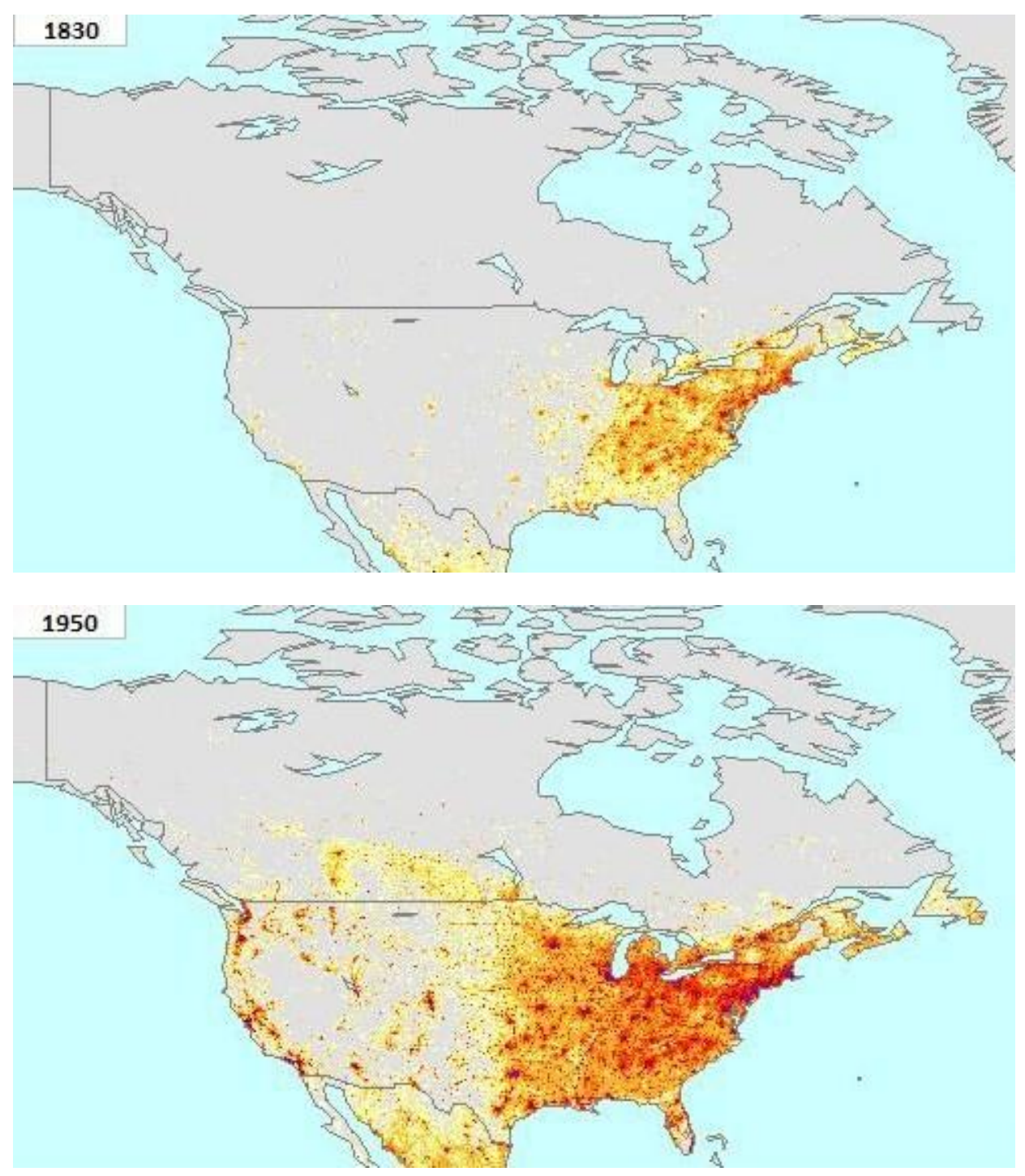


\section{Figure 2.e. Southern Cone: Argentina, Chile and Uruguay}
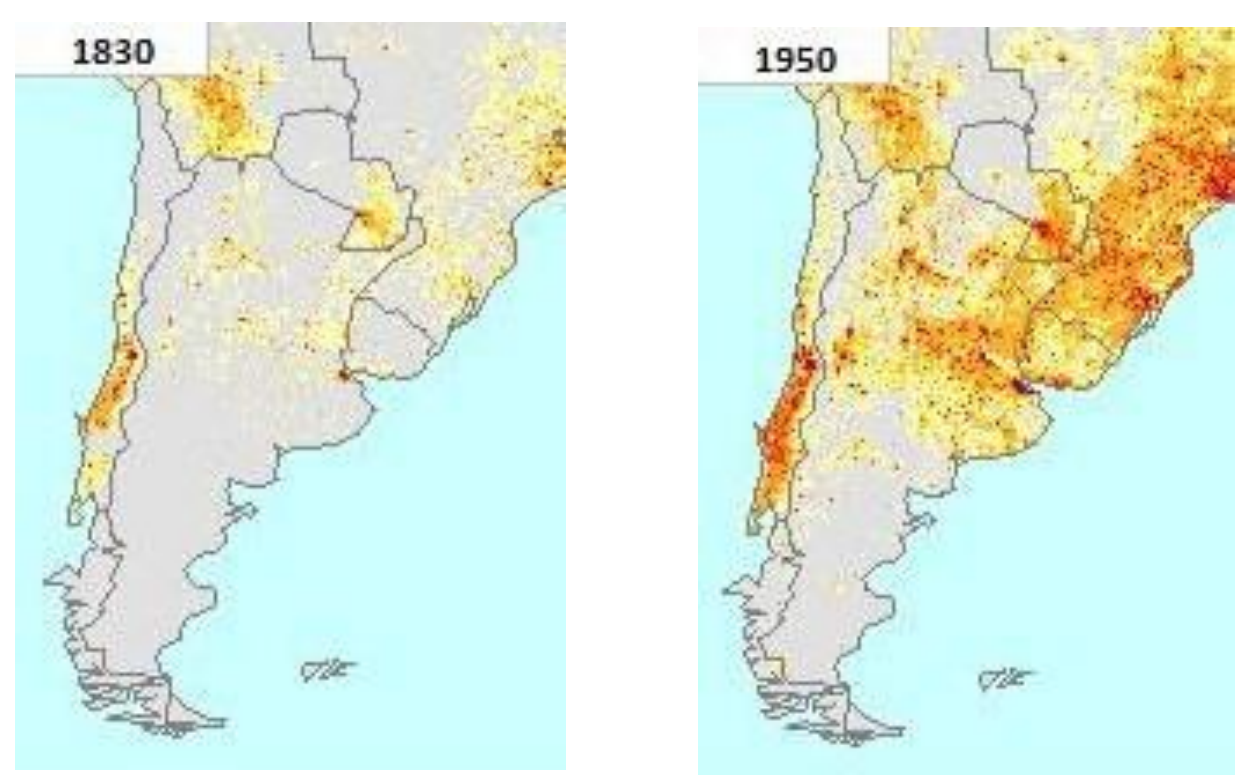

Source: Netherlands Environmental Assessment Agency.

The aim of this exercise is to identify periods in which the process of land frontier expansion was more intense and to capture the dynamism in different regions. In general, the evidence shows that the location of new economic activities and the movement and settlement of population was an intense process in the settler countries at the turn of the century, but it became exhausted before the 1930 s and the evolution within the club was not homogeneous.

Initially Australia's population was located in coastal areas with rural settlements around the wet periphery of the continent, and this was the forerunner of the type of occupation that subsequently occurred in the semi-arid interior (a similar characterization can be found in Williams 1975, pp. 65-66). The south-eastern (Victoria and Tasmania) and north-eastern (New South Wales and Queensland) regions were the first to be occupied and population density was increasing, and it was not until the end of the century that people began moving into the southwest of the country (Western Australia, around Perth). Historically, South Australia and the Northern Territory have the characteristics of an open frontier and the advance of the settlers on territory was disperse and less intense. In New Zealand in the period 1840 to 1860 , settlers firmly established themselves in a number of areas scattered across both islands. The main initial colonization took place in the areas of Auckland, Bay of Islands, Plymouth, Wanaque and Wellington in North Island, and Nelson, Christchurch and Dunedin in South Island (McKinnon 1997). The area around Auckland, where the colony's seat of the government was located, was the biggest centre of settlement, and most of the population was in North Island (75 per cent). The 
settlement of South Island, with its rugged terrain and extreme climate, was somewhat delayed. However, the form that expansion took changed quickly -particularly with the gold rushes of the 1850s-1860s-, and in 1874 more than a half of the population (55 per cent) was in South Island.

Canada was an immense territory and the early colonizers settled in the east with the initial French colonization in the first half of the $16^{\text {th }}$ century (New France) and the increasing competition for land of English and Scottish settlers from the second half of the $17^{\text {th }}$ century (Newfoundland, Nova Scotia, and the region of Hudson Bay). It was not until the last decade of the $19^{\text {th }}$ century that the fertile central prairies were intensively occupied in a process that was made possible by the coming of the transcontinental railways.

Following a brief period of Portuguese dominance in the area, South Africa went through two major periods of colonization. The first one was that of the Dutch Cape Colony from the mid $-17^{\text {th }}$ century. The initial intention was not to colonize the region but to establish a secure base camp where passing ships could obtain protection and provisions. The relationship with the native population (Khoikhoi) was not friendly and early was admitted the participation of free farmers (burghers) that steadily increased in number and began to expand their farms further north and east into the territory. British seized the Cape in 1795, then briefly relinquished it back to the Dutch (1803), before definitively conquering it in 1806 and get the international recognition of the British sovereignty over the area (1815). The rest of the century was characterized by continuous disputes between British, Boers and native population (Zulus), the territorial expansion to the north and the east, the creation of Boer Republics (Transvaal and Orange Free State), a couple of Anglo-Boer wars (1880-1881 and 1899-1902) and the construction of the Union of South Africa in 1909 (Cape Colony, Natal, Transvaal, and Orange Free State). However, in relation with land frontier expansion, the discover and exploitation of mineral wealth -diamonds in Kimberley (1869) and gold in Transvaal (in the second half of the 1880s)- led to an obvious instability with deep consequences in social, demographic and political terms.

In the Southern Cone of South America the expansion of the frontier around the River Plate followed more or less the same pattern in Uruguay, the Argentinean provinces of Buenos Aires (around the port), La Pampa and Córdoba (in the west-centre), Santa Fe and Entre Ríos (on the Littoral) and even in the south of Brazil (Rio Grande do Sul). In Chile the most intensive settlement was in the Núcleo Central. During the last two decades of the century, Chile progressively expanded to the north after the Guerra del Pacífico (1879-1883) and took over land with rich nitrate deposits. During the first decades of the $20^{\text {th }}$ century, the settlement of the South was associated with agricultural expansion after the defeat of the Araucanian.

Our mapping offers another interesting subject, the early development of large cities as land frontier expansion was accompanied by a quick urbanization process. Clear examples of this are Sydney, Melbourne, Adelaide and Perth in Australia, Auckland and Wellington in New Zealand, 
Ottawa and Quebec in Canada, Cape Town and Johannesburg in South Africa, Santiago in Chile, Buenos Aires, Rosario, Tucumán and La Plata in Argentina and Montevideo in Uruguay.

\subsection{Settlement and the potential vegetation}

We can describe the movement of population into a territory, but how was the area effectively achievable? Bearing in mind the fourth constraint mentioned above, we do not take the total surface area of a country as a reference for the "maximum frontier" because this option is not consistent with the historical development of the settler economies in terms of production. Is all the territory suitable for the creation of the means (food, clothes) to sustain the population? Are colonizers willing to settle anywhere? Are all places safe enough?

Colonizers will initially settle in places suitable for human habitation. Early settlers in large parts of the planet were quite restricted in their options as to where people could settle and work in agriculture. Geography (swamps, mountains, dense forests, and poor soils), climate (extreme temperatures, wetness) and hostile indigenous populations limited access to many regions. Besides this, large areas of the world could not be reached due to the lack of infrastructure. The early spread of people (and agriculture) was considerably restricted.

What exactly was the "wildness" that $18^{\text {th }}$ and $19^{\text {th }}$ century settlers had to face in our regions? Can we replicate those historical conditions to understand the settlers' decisions and possibilities? Some concepts from environment and climate change literature can be useful to help us answer these questions. Data representative of the world's "potential vegetation" are a proxy for the natural environment that people in settlement times had to confront. The world's potential vegetation is the vegetation that would most likely exist now in the absence of human activities. It has been estimated in accordance with georeferenced information about today's ecosystem frameworks, various other information sources, and some hard work on classification and analysis (Ramankutty \& Foley 1999). We are interested in identifying land able to "support" settlers and potentially able to produce goods for international commodity markets. In the case of the settler economies, a basic condition is to consider land that can be used to raise livestock. An alternative criterion would be to take arable land or land suitable for crops (typically wheat, in our "club"), but this would be an excessively rigorous criterion. Settler economies had extensive areas where it was (almost) impossible to cultivate the land but where cattle or sheep could be reared successfully. Therefore we consider that the "maximum frontier" will include regions that could be used to raise livestock, which in general means the territory's allocation of grassland. Figure 3 shows the distribution of biome types according to the potential vegetation for our economies. Biomes are climatically and geographically defined regions with similar ecological climate conditions such as communities of plants, animals and soil organisms, and they are often referred to as ecosystems (University of California, Museum of Paleontology 2009). 


\section{Figure 3. Potential vegetation: biome types}

\section{Figure 3.a. References}

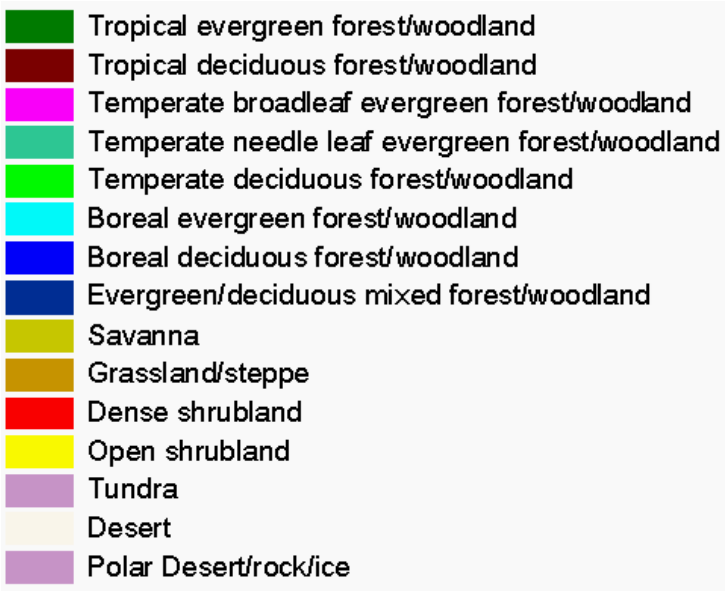

Figure 3.b. Oceania: Australia and New Zealand

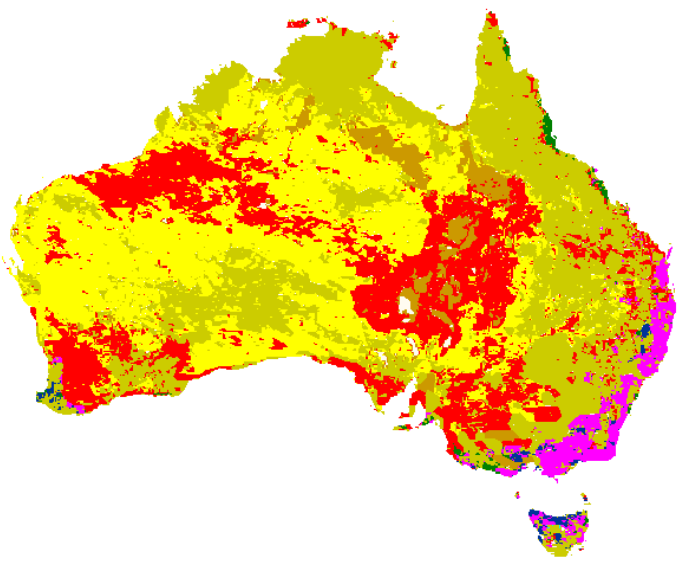

Figure 3.c. Africa: South Africa

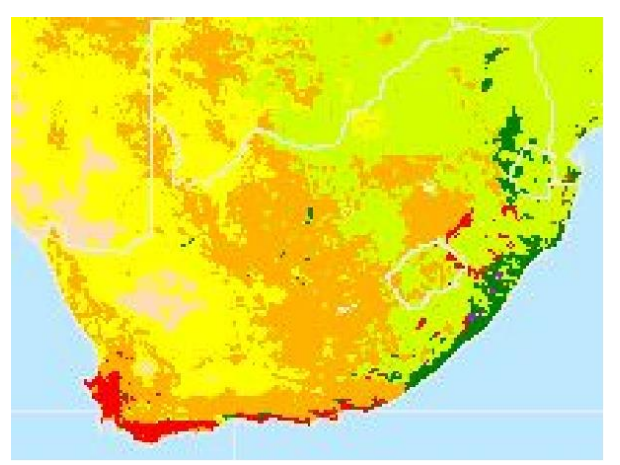


Figure 3.d. North America: Canada

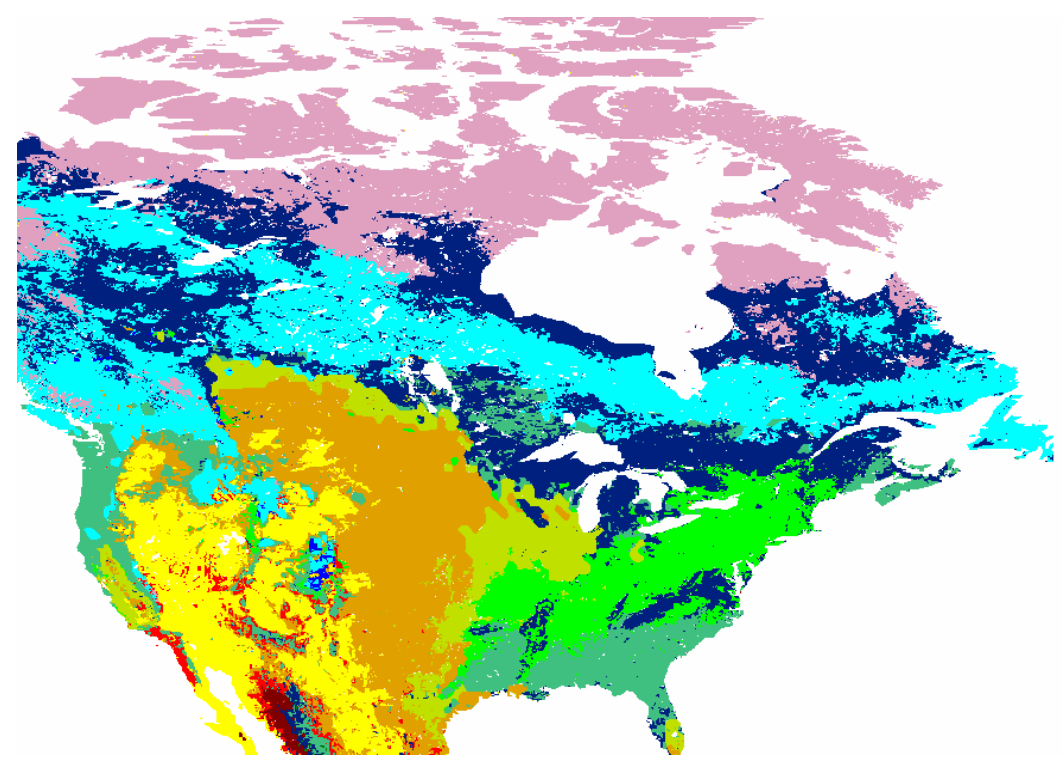

Figure 3.e. Southern Cone: Argentina, Chile and Uruguay

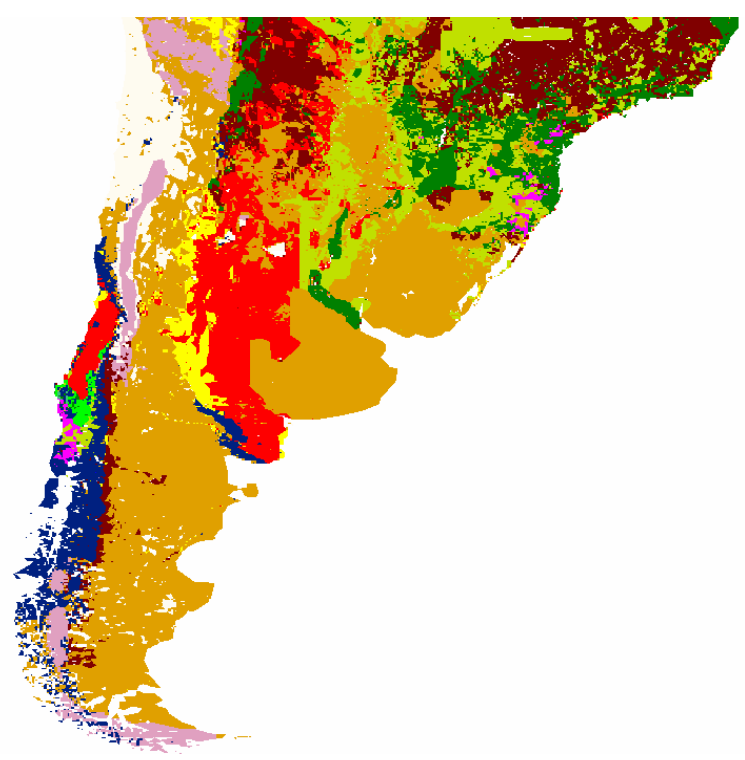

Source: CSGE-Atlas of the Biosphere.

Biome types are defined by plant structures (trees, shrubs, grasses), leaf types (broadleaf and needle-leaf), plant spacing (forest, woodland, savannah) and climate. The biome types that can be classed as grassland are shown in Table 1. Klein Goldewijk \& Van Drecht (2006) assign ordinal 
values and construct a ranking of grasslands including grassland and steppe, open shrubland, savannah, dense shrubland, tundra and several varieties of woodland.

Table 1. Biome types and the allocation of grassland

\begin{tabular}{|lc|}
\hline & Rank \\
\hline Grassland / steppe & 6 \\
Open shrubland & 5 \\
Savannah & 4 \\
Dense shrubland & 3 \\
Tundra & 2 \\
Evergreen / deciduous mixed forest / woodland & 1 \\
Temperate broadleaved evergreen forest / woodland & 1 \\
Temperate deciduous forest / woodland & 1 \\
Temperate needle leaf evergreen forest / woodland & 1 \\
Tropical deciduous forest / woodland & 1 \\
Polar des ert / rock / ice & 0 \\
Boreal deciduous forest / woodland & 0 \\
Boreal evergreen forest / woodland & 0 \\
Tropical evergreen forest / woodland & 0 \\
Hot desert & 0 \\
\hline
\end{tabular}

Source: Klein Goldewijk \& Van Drecht (2006), p.105.

It is clear that settlers faced different "wildness" depending on each country and the land in that country that was occupied. Starting with Oceania (Figure 3.b), in Australia shrubland and savannah predominated and only a very small part of the total was grassland/steppe. In New Zealand, on the other hand, grassland/steppe was the main vegetation biome (although with big differences between the two islands). In South Africa, grassland, steppe and open shrubland dominate a big proportion of the landscape but the first colonizers settled in the dense shrubland. In Canada (Figure 3.c) there was grassland and open shrubland on the prairies but there were large swathes of tundra and boreal forest between this central region and the Atlantic and Pacific coasts. Finally, in the Southern Cone (Figure 3.d), grassland predominated in Argentina and Uruguay, and the wide range of variation in Chile from hot desert in the north to polar desert in the south is obviously represented by the succession of colours. Therefore, we consider the "potential vegetation grassland" (PVG) area of each country -rank 1 to 6- as that part of the national territory suitable to graze livestock and, in consequence, it represents the concept $N$ presented previously (equation 5 ).

\subsection{Frontier expansion, agricultural aptitude and distance}

Soils are not homogeneous throughout a territory, climate changes and terrain slopes differ significantly, and this imposes a specific set of constraints and creates different conditions for the development of agricultural activities. The ranking shown in Table 1 enables us to distinguish three land types as "high", "medium" and "low" aptitude for grassland. We group categories 6 and 
5, 4 and 3 and 2 and 1 (the summed area represents our potential vegetation). Based on this we can construct the indicators presented in equations (1), (2) and (3) where:

\begin{tabular}{|c|c|}
\hline & Land endowment corresponding to: \\
\hline$N_{H}$ & 6,5 \\
\hline$N_{M}$ & 3,4 \\
\hline$N_{L}$ & 1,2 \\
\hline & Land occupied corresponding to: \\
\hline$N_{h}$ & 6,5 \\
\hline$N_{m}$ & 3,4 \\
\hline$N_{l}$ & 1,2 \\
\hline
\end{tabular}

Is it enough to know the agricultural aptitude to qualify the occupied land? In settler economies the land quality not only depended on the agricultural aptitude but also on the distance from the production regions to the markets and, especially in the case of settler economies, to the ports. The effective materialization of the natural wealth was in the possibility to participate in the international markets of commodities. For instance, our indicator must consider that excellent soils very far located are, in facts, bad soils in productive and economic terms. How can we consider any idea about distance?

In the recent literature several concepts derived from the Economic Geography are applied to Economic History analysis (Crafts 2005; Martínez-Galarraga 2013; Rosés 2003; Schulze 2007; Tirado et al. 2006). In particular, the "market potential" is a notion that incorporates the distance as a main factor and that may be useful for our purpose. The market potential equation (Harris 1954) can be defined as:

$$
M P_{i}=\sum_{j=1}^{j=n} \frac{M_{j}}{d_{i j}}
$$

Where $M_{j}$ is a measure of the size of region $j$, usually the GDP, and $d_{i j}$ is the distance, usually represented as the bilateral transport costs between $i$ and $j$.

In our case, we estimate an indicator of "land quality" according to the agriculture aptitude "adjusted" by the distance to specific places that, given their economic, political or historical conditions, result a sort of "centre of gravity". We consider a place in these terms when it represented a geographical point that spread population in different directions and/or had relevance as a connection with international markets. 
Georeferenced information presents data in terms of grid cells, and our database represents the distribution of population with a global $5 \times 5$ minute resolution; therefore we have grid cells that are approximately $8.3 \mathrm{~km}$ in length, $11.8 \mathrm{~km}$ in diagonal and have a surface area of $69.4 \mathrm{~km}^{2}$. Theoretically, the cost of clearing land is an increasing function on the quantity of land incorporated into production (Findlay 1995; Findlay \& Lundahl 2001) or, equivalently, the marginal returns of each unity of land incorporated is lower. We can apply this idea here and consider that each cell incorporated into production has a different area that depends on its distance from the centre of gravity. As a result, $69.4 \mathrm{~km}^{2}$ would be an "average" of the closer cells (that have high values) and the distant cells (that have low values). We need a coefficient that "rewards" the former group of cells and "penalizes" the latter, and we use a measure of distance between each cell and the centre of gravity. We multiply the area of each cell by the inverse of the minimum distance to a centre of gravity and then we re-scale the total surface of each type of land to maintain the true cell average $\left(69.4 \mathrm{~km}^{2}\right)$. It is important to re-scale the series so we keep the total surface of endowments and hence we can make comparisons. Note that we have as many values of distance as number of occupied cells and that we consider the minimum distance to a centre of gravity for the correction. With this we assume that the closer is the centre of gravity the higher is its influence in the economic activity of the corresponding cell.

How can we make our definitions operative? Settler economies based their growth on external conditions associated with the First Globalization, so ports are natural candidates to be considered "centres of gravity" or expansion axes. We assume that the producers decide to direct their products to the closest port in the province, state or large region. It is impossible to know the real destination of the production but we consider that our assumption is reasonable. In cases in which there is another type of "centre of gravity", we can argue about the feasibility of our assumption. We consider air distance instead of the "real distance" that represents the inclusion of geographical accidents, infrastructure and transport costs (they will be specially considered in next stages of the research). Maps, regions and centres of gravity are presented in Figure 4.

The 1910 Official Yearbook of Australia includes a description of the main ports of the Commonwealth classified by states and ranked by importance in the region (Figure 4.a). We choose one port per state as a reference. In New South Wales we consider Port Jackson, which is the harbour of Sydney city. In Victoria, we consider Port Phillip in the Hobson's Bay at the mouth of Yarra River, which is the harbour of Melbourne city. In Queensland, the most important port is Brisbane, which is at the mouth of the Brisbane River close to Moreton Bay. In South Australia, we consider Port Adelaide in the city with the same name. In Western Australia, since the beginning of the $20^{\text {th }}$ century the most important port has been Fremantle, at the mouth of Swan River and $19 \mathrm{~km}$ southwest of Perth. North Australia only had one main harbour, Port Darwin, in 
the city with the same name. Finally, Tasmania had several ports and the most important was Hobart, at the mouth of Derwent River. ${ }^{3}$

Figure 4. Centres of gravity

\section{Figure 4.a. Australia}

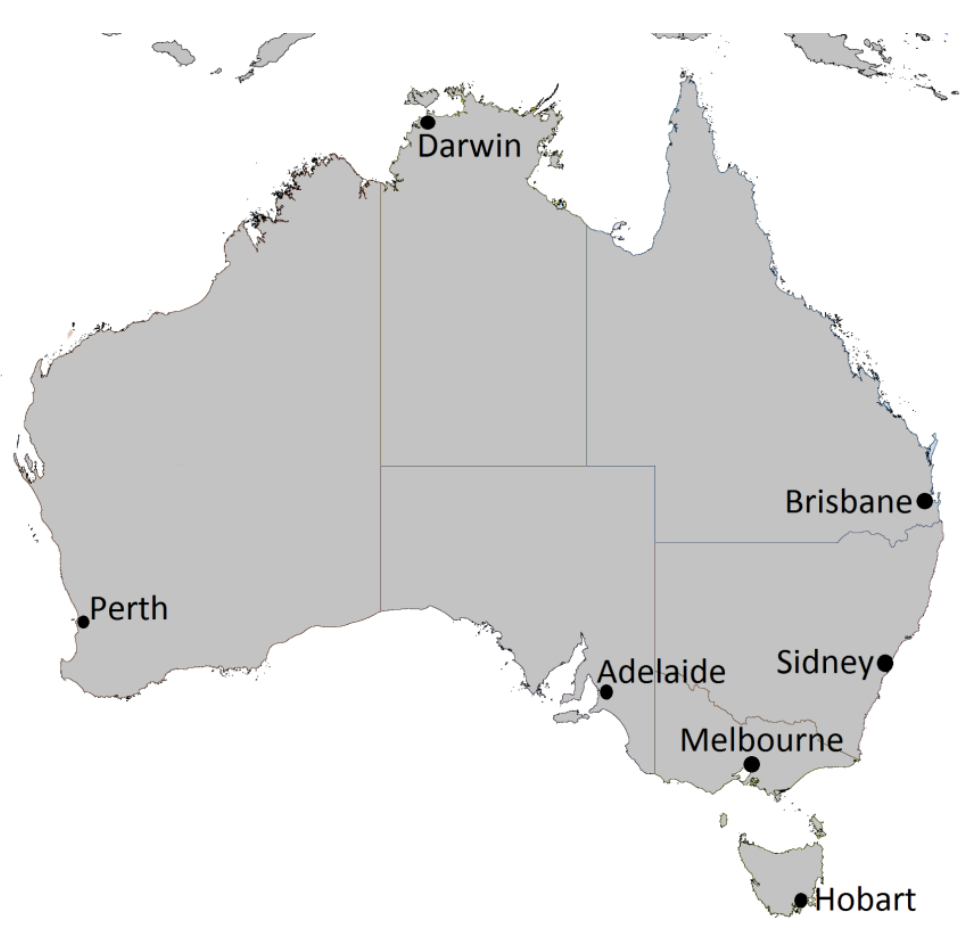

In Argentina (Figure 4.b) the most important port was Buenos Aires, while the other harbours in the Republic were fundamentally specialized in coasting ship. The national census of 1914 reported that 56 per cent of all cargo went to Buenos Aires (including sailing and steam ships) and that almost 180 of the 610 vessels were large ships (deep draught). We use Buenos Aires as one of our reference markers for distance. However, we also need to consider a second reference because land expansion in Argentina developed along two axes.

The coastal and Pampas (pampeana) regions developed from the beginning of $19^{\text {th }}$ century with a strong foreign stimulus and Buenos Aires was their port. But there was also the inland Andean (andino) region, which had its roots deep in the colonial past of Spanish South America, which had always been centred on Alto Perú (Bolivia) and the rich zone of Potosí, and this area influenced the north of Argentina (Cao \& Rubins, 1996). Tucumán city was one of the most

\footnotetext{
${ }^{3}$ Coghlan (1904), pp. 222-223, notices that some figures -such as statistics from Melbourne- are inflated because the great ocean steamers were counted twice (entering the port and leaving). However, this limitation is not important for our purposes because the adjustment does not change the ranking within each state.
} 
important economic and political centres. It had strong demographic development and was located in a region with a productive structure based on plantations (sugar), which contrasted with the pastoral activity of the south and east of the country. We take it as our second reference point for distances.

Figure 4.b. Argentina

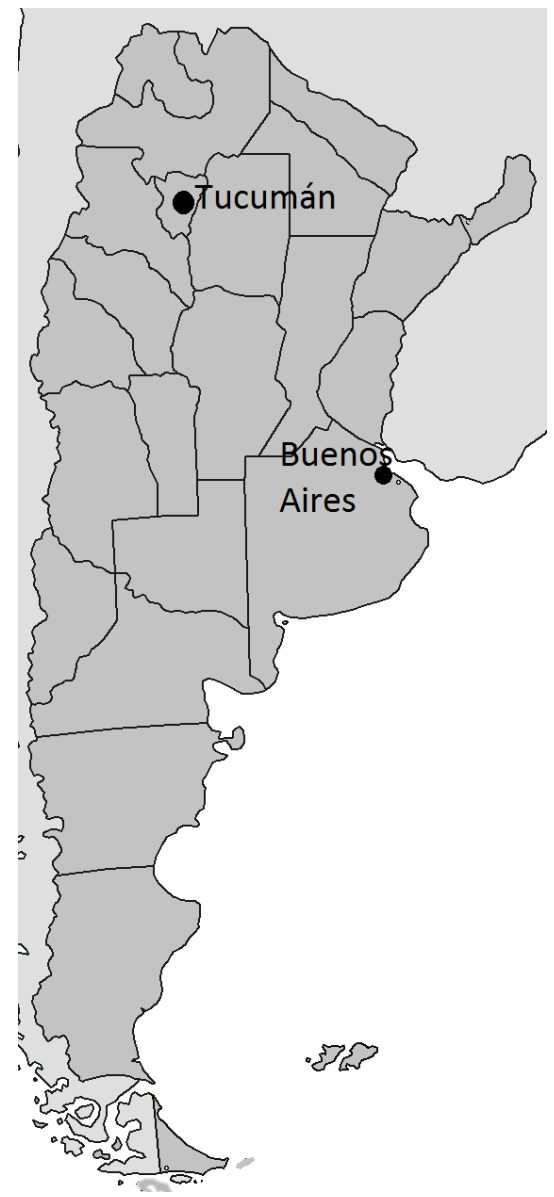

Canada is a very large country with Atlantic and Pacific coasts and initially it would be suitable to consider both these "exit doors" to international markets (Figure 4.c). In 1913-1914, the four most important ports in the country in terms of cargo shipped were Halifax and Montreal on the east coast (in Nova Scotia and Quebec provinces, respectively) and Vancouver and Victoria on the west coast (both in British Columbia). Both ports in the east handled approximately the same amounts of cargo in tonnage 4 but average cargo per vessel was significantly greater in Montreal, so we take this as our eastern reference point. In the west, there are only minor differences between Vancouver and Victoria and they are located very near each other (Statistics Canada,

4 Annual averages 1913-1914: Halifax 3.5 million tons, Montreal 3.9 million tons. 
1914, p.474, and 1915, p.501-502). However, an examination of the dynamics of settlement raised doubts about the importance of these two ports as "centres of gravity".

The demographic development of the middle areas of the country was more related to expansion from the east than from the west, so we need an alternative distance reference point. Winnipeg, the capital of Manitoba, is near the longitudinal centre of North America, in south central Canada, close to the eastern border of the Canadian Prairies, at the confluence of the Red and Assiniboine Rivers. Historically, this area played an important regional role as a fur trading post ( $18^{\text {th }}$ century) and as an important post for the Hudson's Bay Company (during the first half of the $19^{\text {th }}$ century), and it enjoyed rapid progress after the coming of the Canadian Pacific Railway in 1881.

\section{Figure 4.c. Canada}

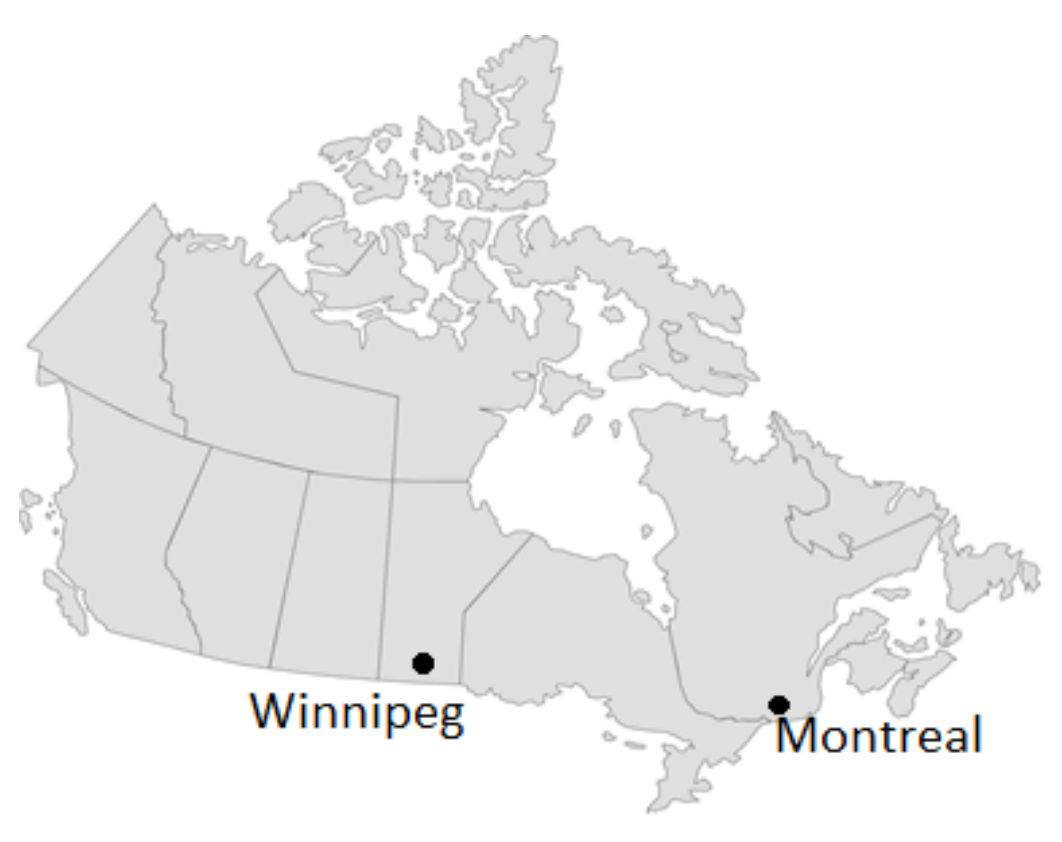

Historically, Cape Town is a centre of gravity in South Africa (Figure 4.d); the original creation by strategic reasons transformed the settlement in a centre of expansion, with political and social influence on the rest of the country in the long run. However, the mineral discovers and exploitation in the north and east of the country created a different and specific demographic dynamics that requires considering an additional centre of gravity. We choose Johannesburg as the other reference to measure distance because it constitutes the biggest city of the country. 
Figure 4.d. South Africa

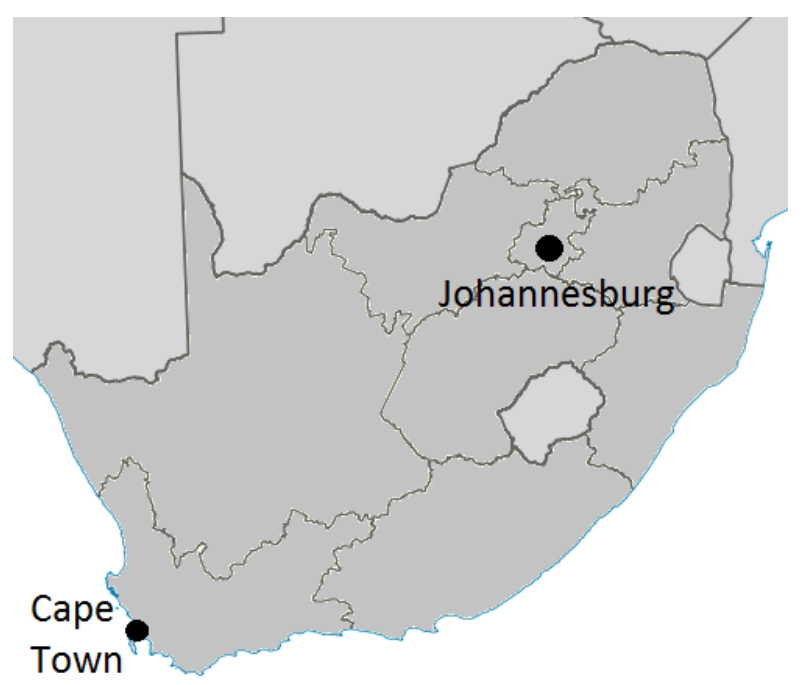

Figure 4.f. New Zealand

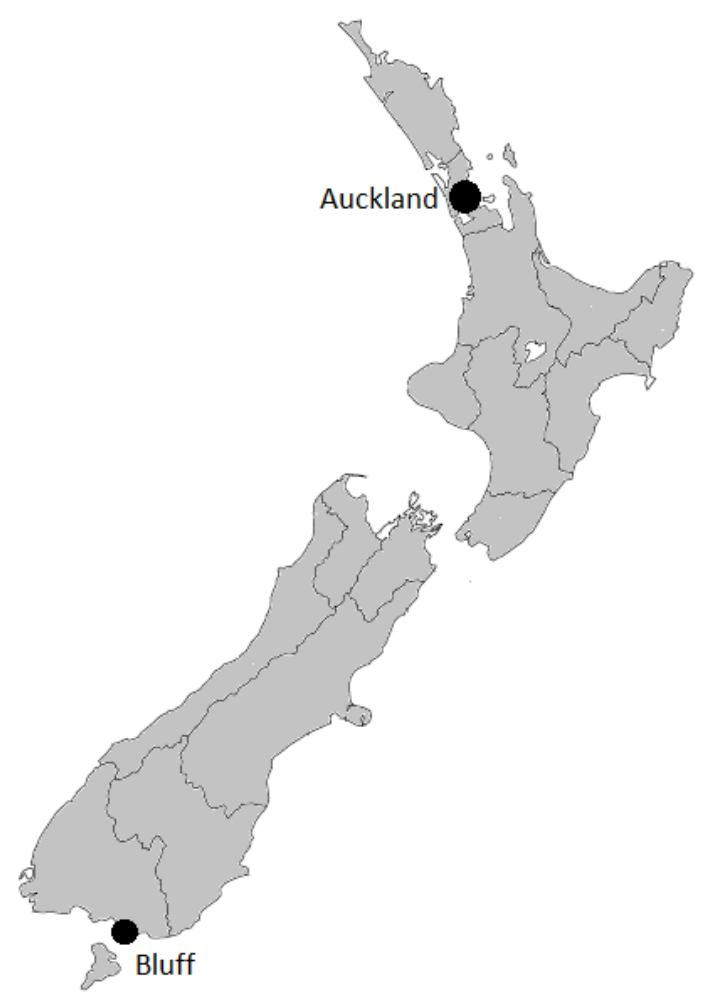

Figure 4.e. Chile

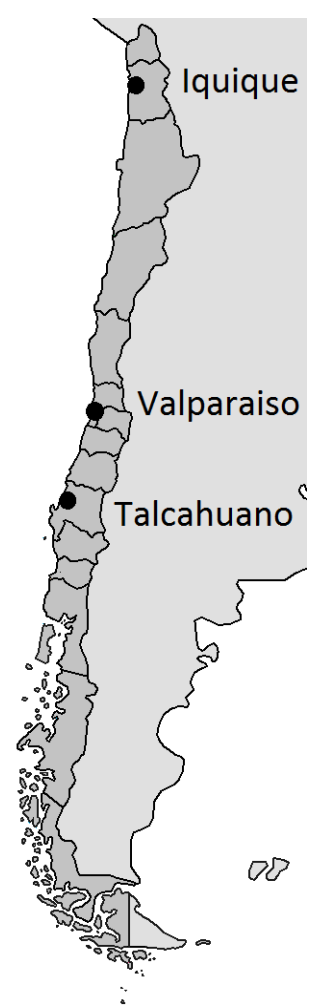

Figure 4.g. Uruguay

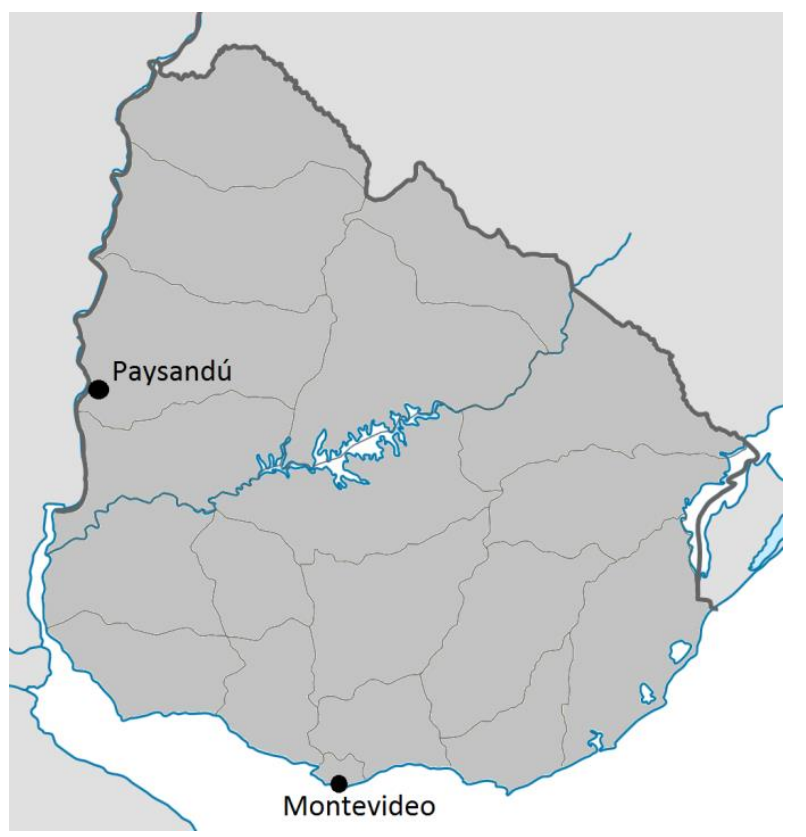


When we come to the small economies in our "club" it may be interesting to consider some geographical conditions also. Chile is $4,270 \mathrm{~km}$ long and an average of $175 \mathrm{~km}$ wide, and it has a particular shape that gives it almost all kinds of climates and very varied topography (Hurtado 1966). We can consider three ports as distance reference points, corresponding to the North (Tarapacá, Antofagasta, Atacama, Coquimbo and Arica y Parinacota), South (Arauco, Bío Bío, Concepción, Araucanía, Los Ríos, Los Lagos, Aisén del General Carlos Ibáñez del Campo and Magallanes and Chilean Antarctica) and Núcleo Central (Valparaíso, Santiago, Libertador General Bernardo O'Higgins, Maule, Nuble) regions (see Figure 4.e). In the North the main port was Iquique, in Tarapacá, followed by Tocopilla and Antofagasta in Antofagasta province. In 1910, the former exported a volume of nitrates that exceeded the total for both the other ports together (Cariola \& Sunkel 1982, p. 133).5 In the South, the most important port -especially for the trade in cereals such as wheat- was Talcahuano, which at the end of $19^{\text {th }}$ century and the first decades of $20^{\text {th }}$ century exceeded the movement of other ports such as Constitución or Tomé. Finally, the main port in the Núcleo Central, the region with the highest population concentration and with a long history of agricultural development, was Valparaiso, which dates from the colonial times. Therefore we could use three ports as distance reference points: Iquique, Talcahuano and Valparaiso.

New Zealand is made up of two main islands. At the beginning of $20^{\text {th }}$ century, the two ports with the greatest total tonnage entered and cleared were Auckland in North Island (followed closely by Wellington) and Bluff Harbour in the South Island (Coghlan 1904, p. 223) (Figure 4.f). However, in South Island there is another interesting geographical case for our exercise: Christchurch. The urban development of this city would have justified choosing it as our distance reference point although it is (relatively) close to the port and results will not differ.

Finally, in Uruguay, since colonial times Montevideo has been the main port, the principal city of the country and the "exit door" to the international economy (Figure 4.f). However, recently, the discussion about a second spatial regionalization up north of the territory, historically articulated with the Misiones Orientales and oriented to domestic markets has arisen (see Moraes 2008). This space would include the region contained by the rivers Negro, Uruguay, Ibicuy and lake De los Patos in Brazil in the Atlantic bank. We select the city of Paysandú as the centre of gravity, along the Río Uruguay, because it was the traditional port connecting the Argentine littoral and the Brazilian south with the River Plate and the international markets.

\footnotetext{
5 About the ports of the northern region see Badía-Miró (2008). 


\subsection{Data}

Recent literature related to the negative effects of economic growth on environment and the global climatic change includes historical approximations to the evolution and geographical location of people, consumption and production in a world scale.

The "Netherlands Environmental Assessment Agency (MNP)" includes two programmes: the History Database of the Global Environment (HYDE 3.1) and the Integrated Modelling of Global Environmental Change (IMAGE) and information about population is available on their website. Data corresponding to biome types derives from Atlas of the Biosphere, a product of the Centre for Sustainability and the Global Environment (SAGE), part of the Nelson Institute for Environmental Studies at the University of Wisconsin, Madison.

\section{Land frontier expansion in terms of "quality": our results}

We propose several measures of the land frontier expansion from 1830 to 1950 considering two hypotheses: (i) the land frontier expansion was a Ricardian process according to the extensive margin; (ii) the land frontier expansion was a Ricardian process that follows an intensive margin in the use of land. For both cases, we present our indicators by country, considering the measures according to the land quality; i.e. considering natural conditions and distance to the centres of gravity which constitute the more suitable measure.

\subsection{Land frontier expansion and the extensive margin}

We present the evolution of the indicators $\lambda_{h}, \lambda_{m}$ and $\lambda_{l}$ (and $\lambda$ as consequence). An increasing trend means the expansion of the land frontier (the reduction in the "open frontier") and represents the incorporation of land to the agrarian production with an economic orientation. Each type of land is presented in the graph considering the weight in the total expansion; i.e. $\lambda=w_{H} \lambda_{h}+w_{M} \lambda_{m}+w_{L} \lambda_{l}=\Lambda_{h}+\Lambda_{m}+\Lambda_{l}$ represent the weighted sum of each type of land $(h, m$, and $l$ ) devoted to the production and where $\Lambda_{h}, \Lambda_{m}$ and $\Lambda_{\mathrm{l}}$ approach to 1 in the long run and $o \leq w_{h}, w_{m}$, $w_{l} \leq 1$. We consider indicators in terms of land quality which means we consider land aptitude corrected by distance.

We find support for the Ricardian hypothesis in Argentina (Figure 5), Uruguay (Figure 6) and New Zealand (Figure 7).

The First Globalization and the boom of the prices of commodities that characterized the period from the 1870 os onwards encouraged the incorporation of "new" land onto the production 6 and, specially, those that presented better agrarian conditions for crops and rearing livestock and

\footnotetext{
${ }^{6}$ In the case of Argentina the difference quality index presents positive values since 1870s-1880s.
} 
where relatively near centres of gravity, with ports and large markets. These evolutions contrast with the other members of the club.

Figure 5. Land frontier expansion according to extensive margin: Argentina

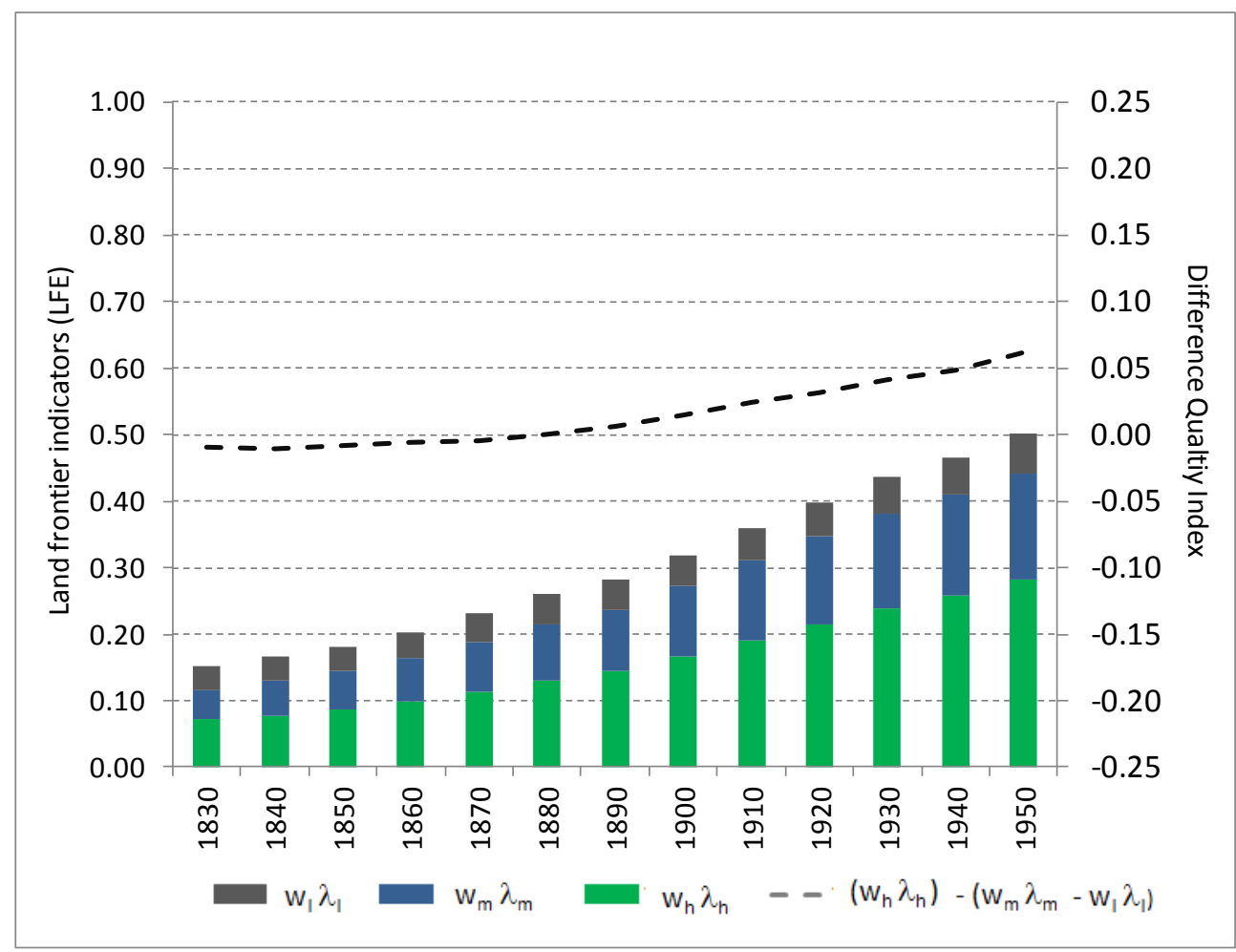


Figure 6. Land frontier expansion according to extensive margin: Uruguay

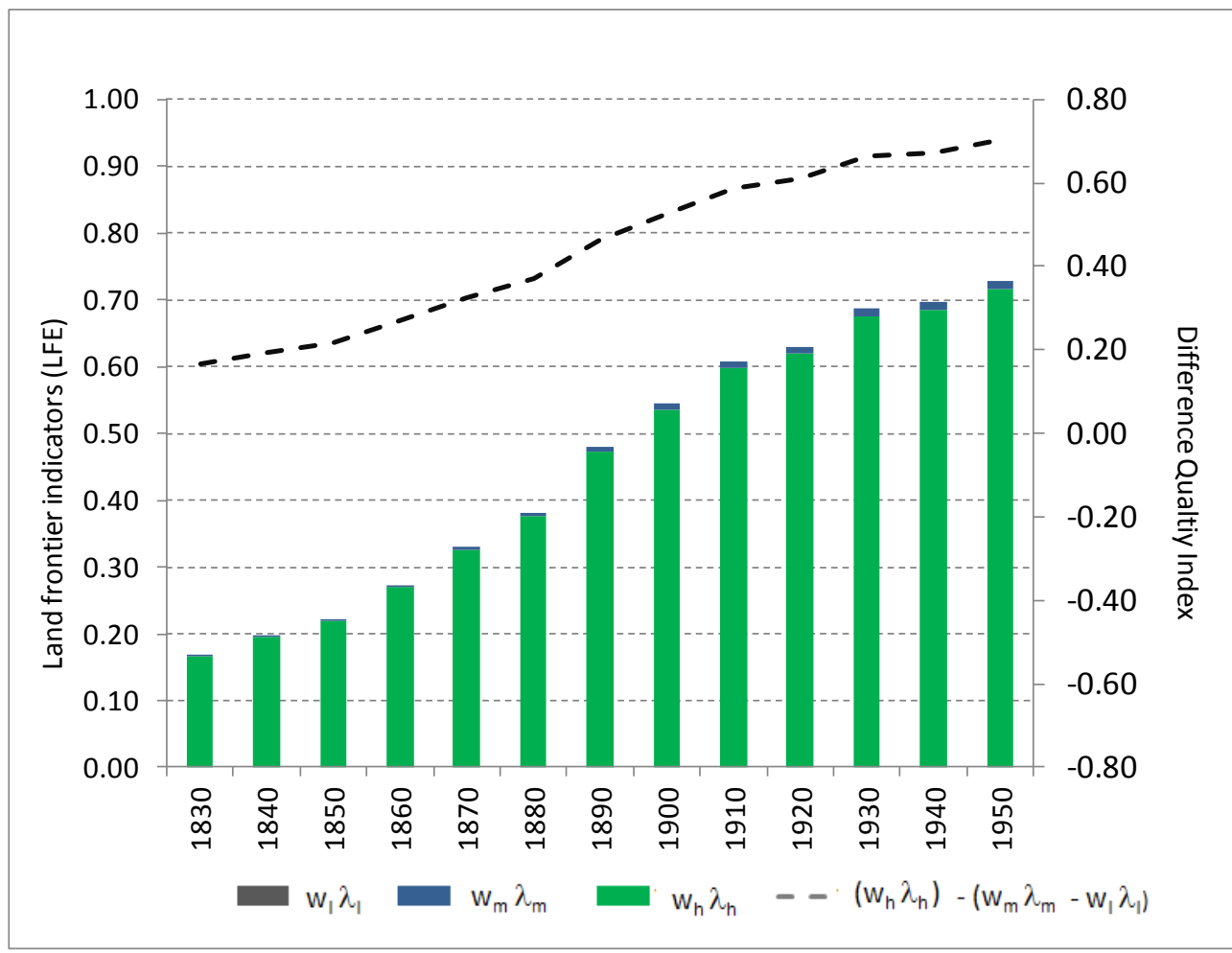

Figure 7. Land frontier expansion according to extensive margin: New Zealand

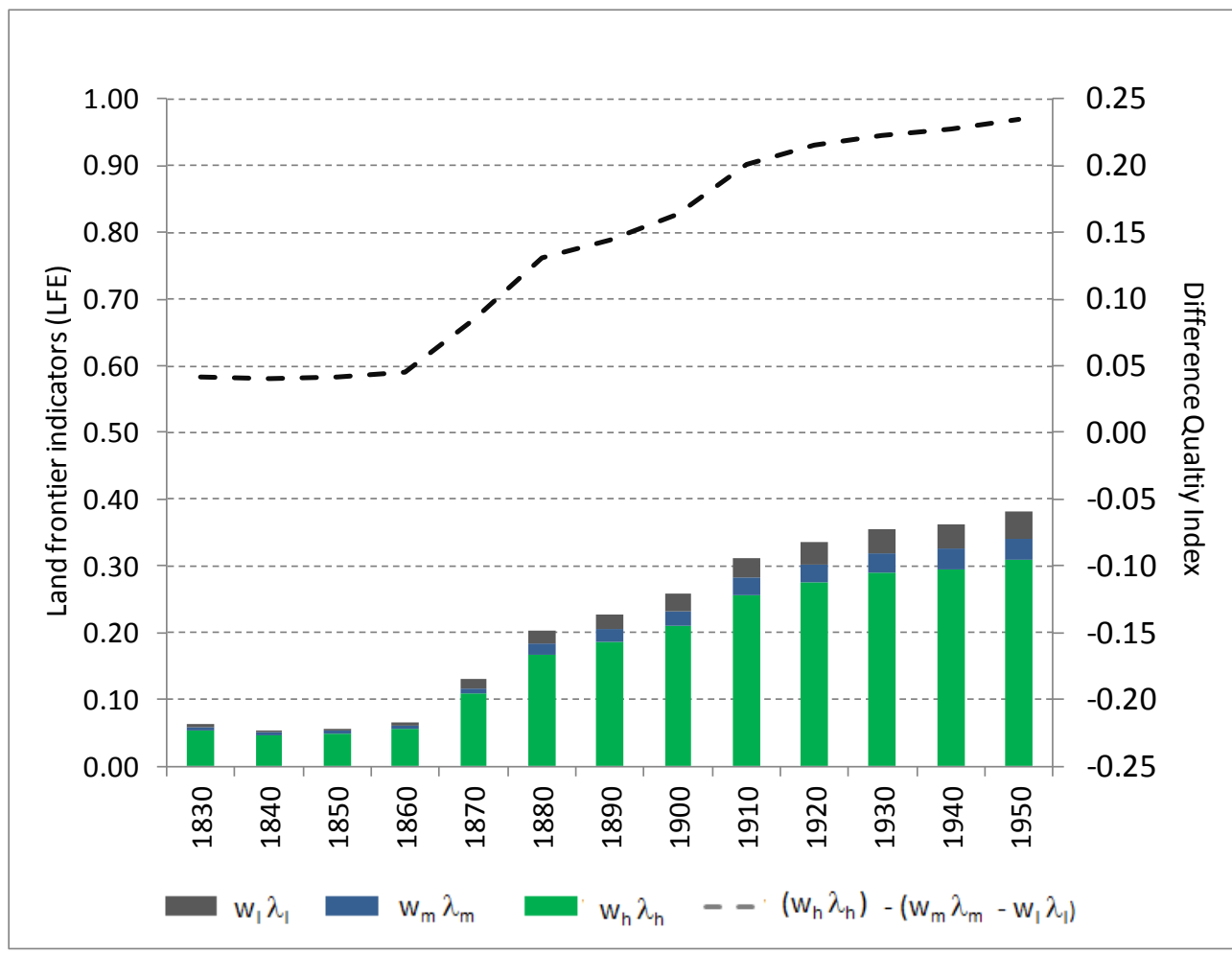


Australia (Figure 8), Canada (Figure 9) and Chile (Figure 10) presented a significantly less intense process of land frontier expansion where the high land quality maintained a secondary role (our difference quality index presents negative values). However, the timing and the characteristics of the process differ. The expansion of the frontier in Australia occurred earlier than in the other countries (1830s-1860s) and before the clearest effects of the First Globalization. It is probable that this evolution was related with the mining expansion of those years (especially in the 1850s) and the "gold rush" era of Australia. In Chile, the frontier expansion was a very moderate process and the clearest change corresponded to the period 1870-1880 that coincided with the incorporation of "new" territories (from Bolivia and Peru) and the expansion of the low quality land (remember that the north of Chile is a region dominated by arid climate and low conditions for agricultural production). Chile early occupied the land suitable to agriculture and the expansion never constituted a generalised process. Canada was the only economy where despite non-presenting a Ricardian process showed a land frontier expansion that reacted to the stimulus of the First Globalization. Canada started to "close" its frontier from 1870 onwards and this implied to advance through the three types of land to achieve the better lands and settling the "far west".

Finally, South Africa (Figure 11) showed an intermediate evolution between both groups. As the first one, it seemed to react to the effects of the First Globalization and the low quality land maintained a marginal role and, as Canada, the expansion of the land involved high and medium quality land with similar trajectories. 
Figure 8. Land frontier expansion according to extensive margin: Australia

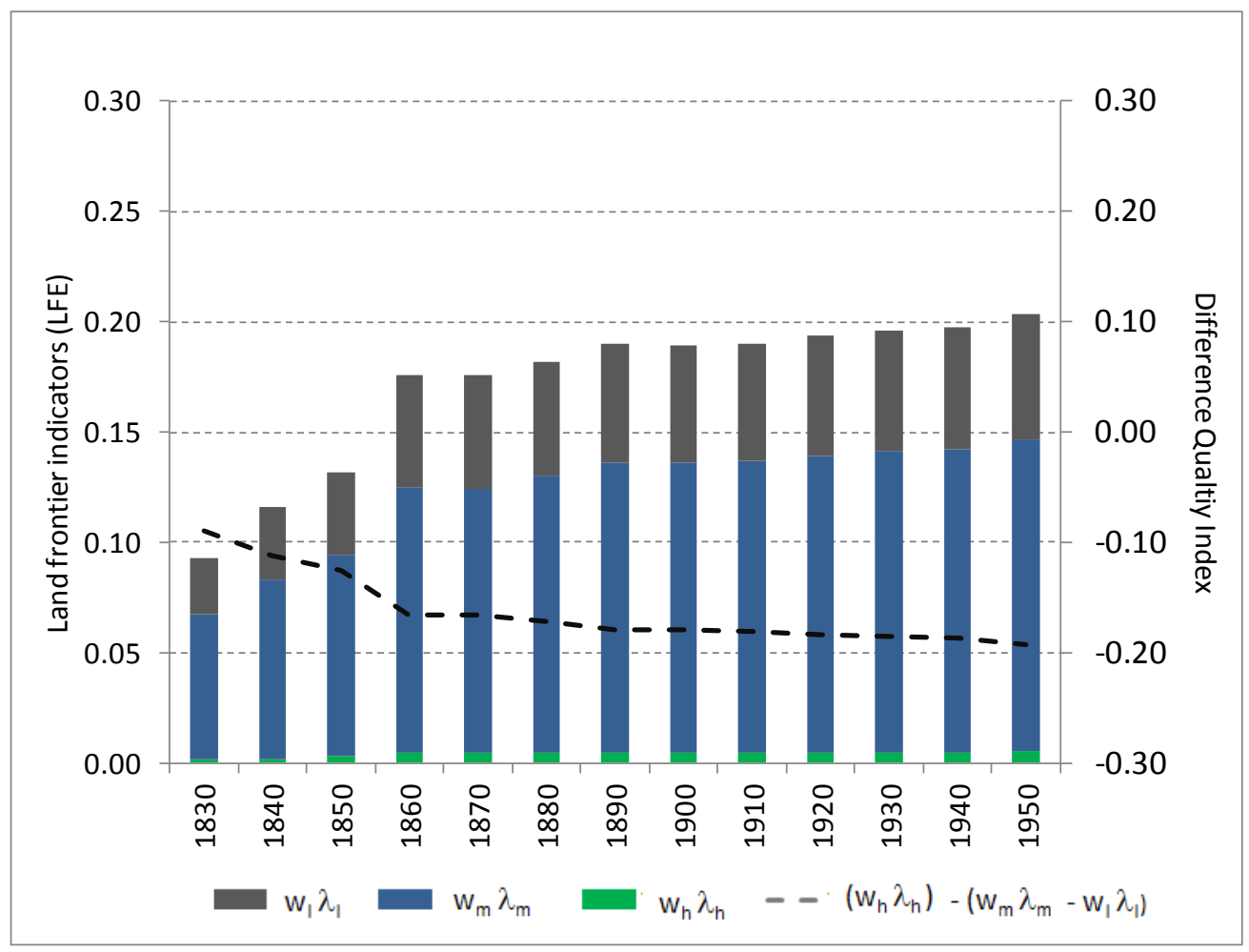

Figure 9. Land frontier expansion according to extensive margin: Canada

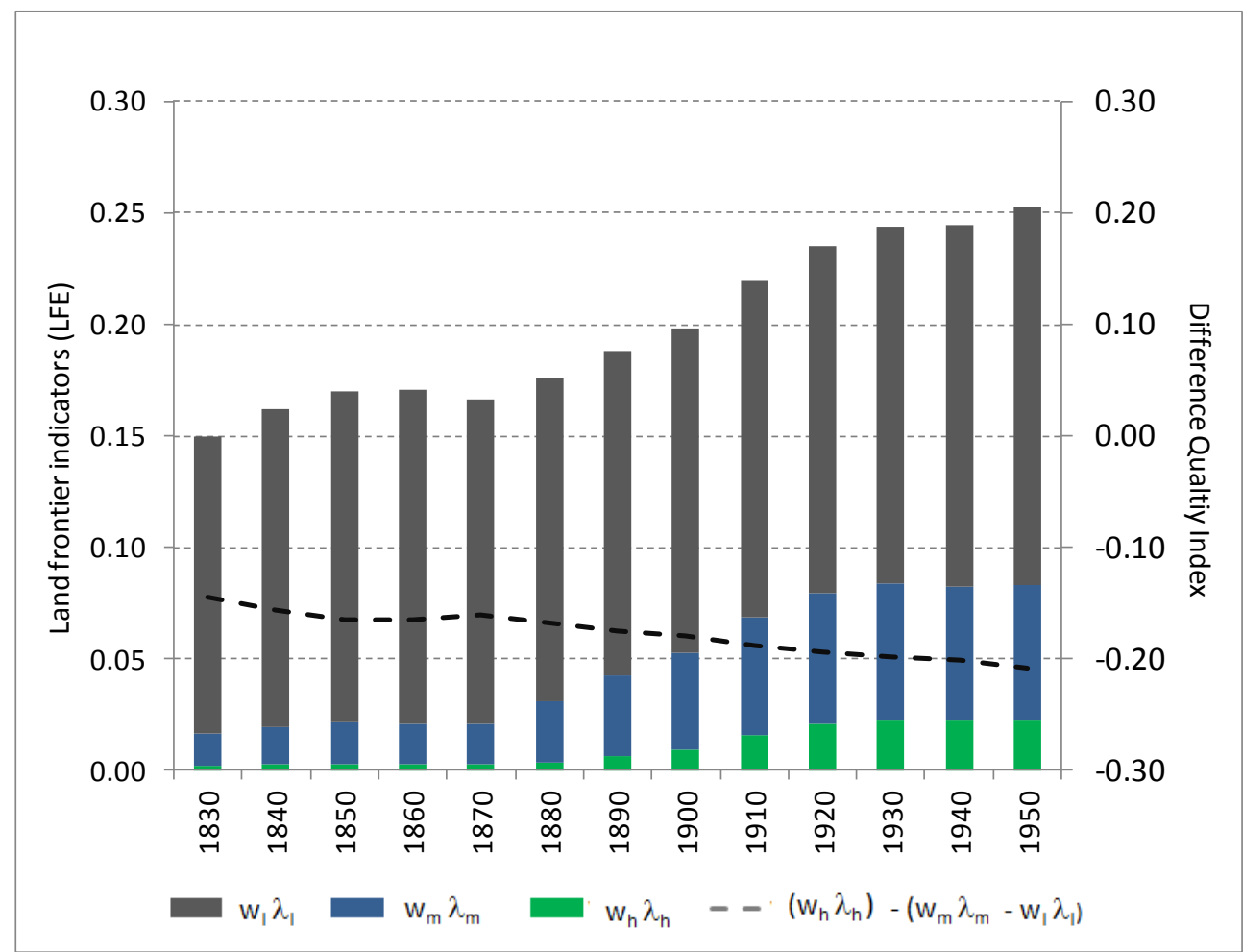


Figure 10. Land frontier expansion according to extensive margin: Chile

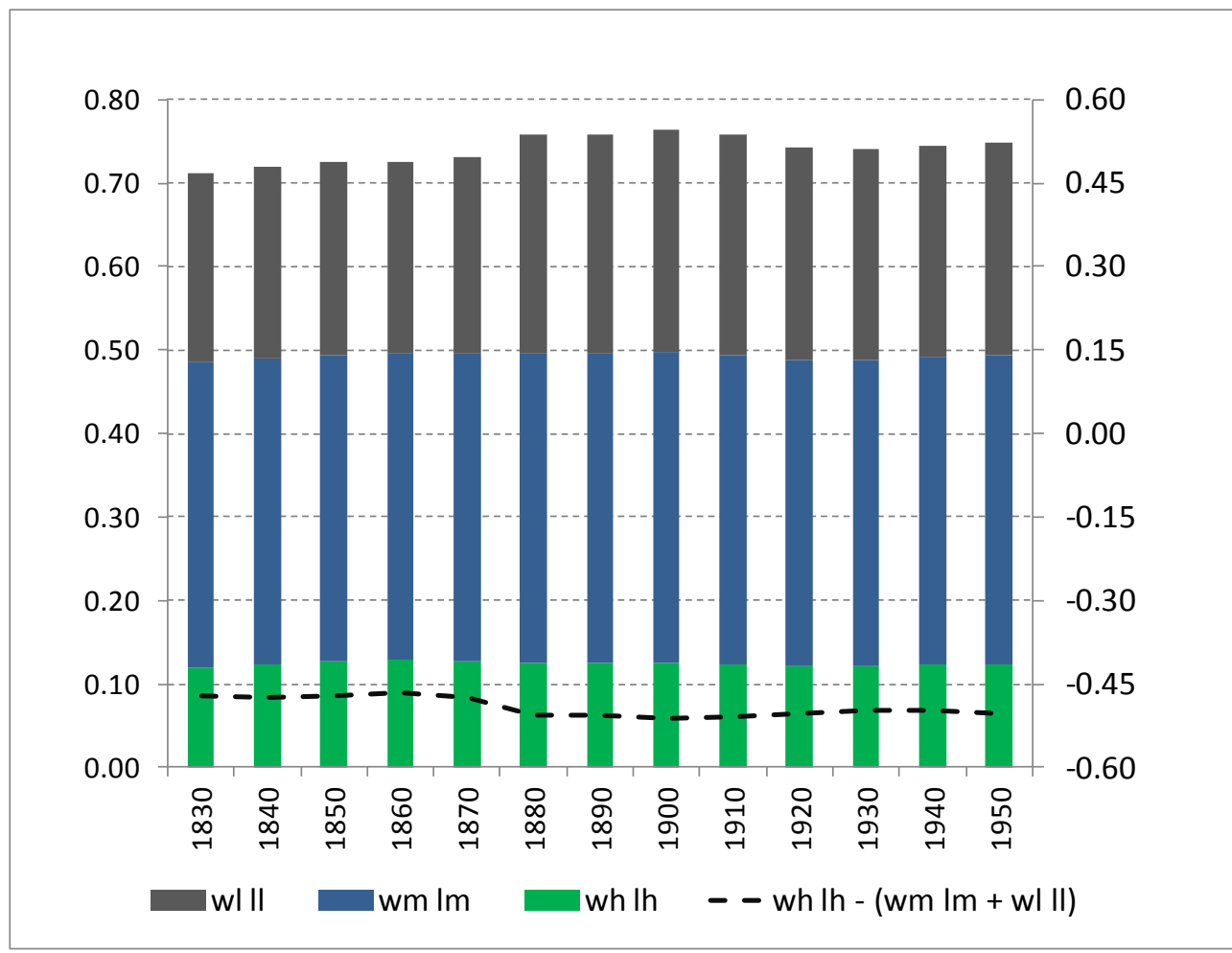

Figure 11. Land frontier expansion according to extensive margin: South Africa

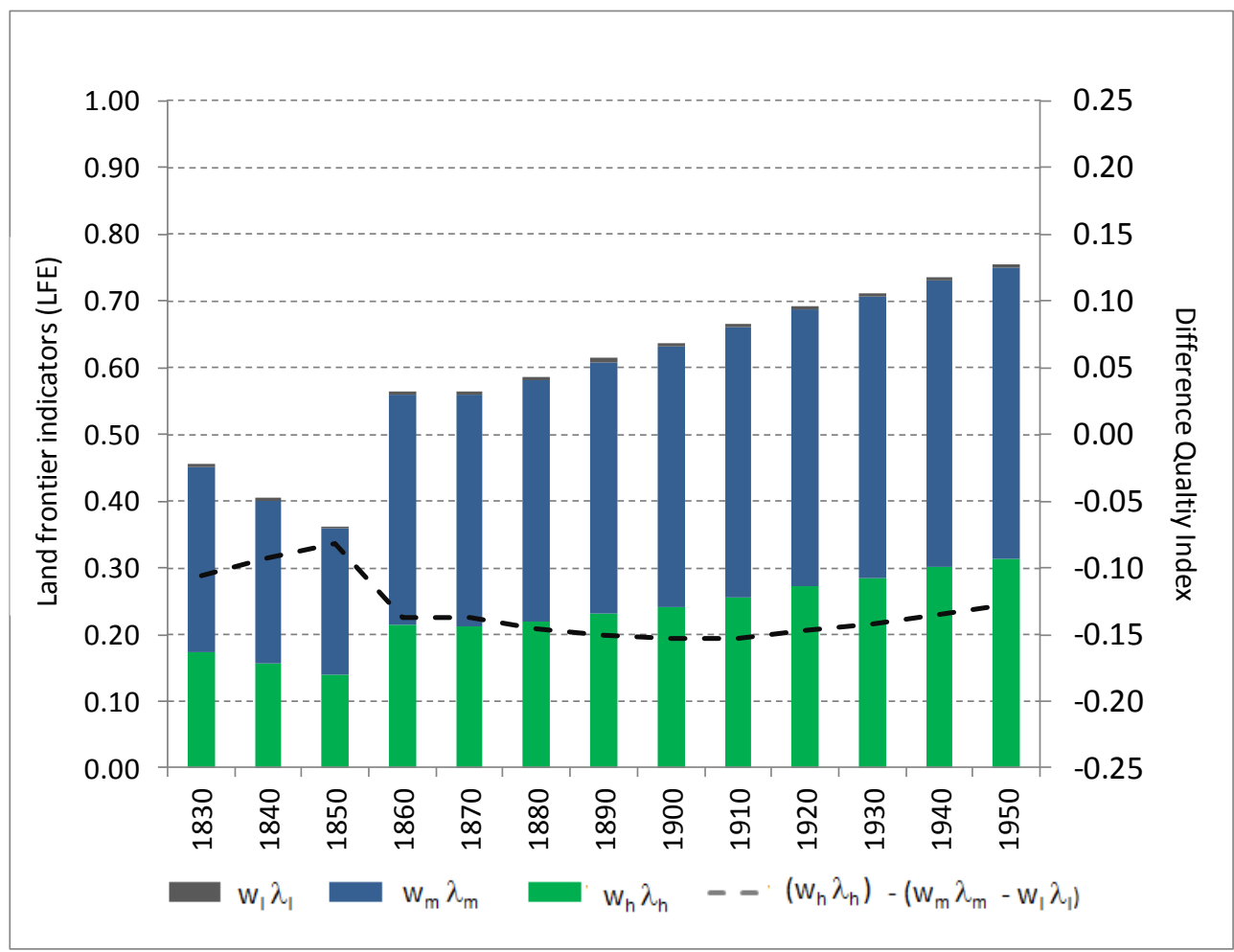


Several factors can explain the differences between both groups but it is evident that the evolution of the indicators depends critically on the magnitude of the endowments. Clearly, it is more likely to run out a type of land when it is scarce in the economy and, simultaneously, the dynamics is determined, at least partially, by the initial location of the first colonizers and settlers (which was not always related to economic conditions). Table 2 presents the shares of each type of land as proportion of total PVG (i.e. excluding those biomes non-adequate to grassland and with nil value in Table 1) ranked by "quality" (aptitude corrected by distance).

Table 2. Biome types and the allocation of grassland

\begin{tabular}{|c|c|c|c|c|c|c|}
\hline & \multicolumn{6}{|c|}{ According to: } \\
\hline & \multicolumn{3}{|c|}{ Aptitude } & \multicolumn{3}{|c|}{ Quality } \\
\hline & High & Medium & Low & High & Medium & Low \\
\hline Canada & $3 \%$ & $2 \%$ & $94 \%$ & $6 \%$ & $9 \%$ & $86 \%$ \\
\hline Chile & $26 \%$ & $13 \%$ & $61 \%$ & $20 \%$ & $38 \%$ & $42 \%$ \\
\hline Australia & $39 \%$ & $57 \%$ & $4 \%$ & $23 \%$ & $65 \%$ & $12 \%$ \\
\hline South Africa & $62 \%$ & $38 \%$ & $1 \%$ & $53 \%$ & $46 \%$ & $1 \%$ \\
\hline Argentina & $65 \%$ & $25 \%$ & $10 \%$ & $61 \%$ & $27 \%$ & $12 \%$ \\
\hline New Zealand & $58 \%$ & $18 \%$ & $24 \%$ & $68 \%$ & $9 \%$ & $23 \%$ \\
\hline Uruguay & $98 \%$ & $2 \%$ & $0 \%$ & $99 \%$ & $1 \%$ & $0 \%$ \\
\hline
\end{tabular}

Source: own elaboration.

The three economies with the lowest shares of high land quality coincide with those that did not experience a Ricardian process -Canada (6 percent), Chile (20 per cent) and Australia (23 per cent)- and, as before, South Africa presents an intermediate situation in terms of the land structure by type of land. In addition, the location of the first settlements explains, at least partially, these differences. In Australia, the initial objective of the British colonizers was the creation of a penal colony and, in South Africa the intention was the establishment of a secure place for the ships that traded with Asia. Production conditions were absolutely secondary in both cases. In Canada, the coastal lands presented deficient conditions for grassland and the achievement of the best soils implied to face high costs in infrastructure and transport. The first European settlements in Chile were located in the best lands for grassland but the share of high quality land run out quickly from the starting of the period. Finally, other factor that explains that Ricardian model does not fit with the experience of some countries is related with the type of natural wealth that economies pose. These four countries relied on big endowments of mineral resources (gold, coal, diamonds, nitrates) whose discover and exploitation changed significantly the political, social and demographic conditions of the colonies or the early nations.

\subsection{Land frontier expansion and the intensive margin}

The relation between the land-labour ratios of high and medium-low aptitude for grassland -equation (11) and Figure 2- shows that agrarian producers would have applied increasing doses of labour more intensively in the first type of land in Argentina -from the 1870s onwards- (Figure 
12.a), Chile (Figure 12.b) and Uruguay (Figure 12.c). Therefore, our evidence does not reject the Ricardian hypothesis of intensive margin when we consider the lands in terms of quality. The evolution in the other members of the "club" was different.

South Africa (Figure 13.c) and New Zealand (Figure 13.d) present increasing trends in the indicators and Canada (Figure 13.b) and Australia (Figure 13.a) show curves with changeable slopes and rising paths during the First Globalization. Therefore, our evidence does not support the intensive margin for these countries. This result is particularly interesting considering the period from 1870 to the 1920 .

The South American Southern Cone (Argentina, Chile and Uruguay) reacted to the First Globalization intensifying (relatively) the production through higher doses of labour applied to the best lands and Australasia, Canada and South Africa did not do it. But this subject gives rise to the limitations of our exercise. We only consider the possibility to intensify the use of land with the incorporation of more quantity of labour per unit of land but the landowners could achieve a deeper intensification with higher doses of capital. In a previous paper (Willebald 2015), we find evidence of increasing profits in the agriculture in the last decades of the $19^{\text {th }}$ century in several countries of the "club" (especially Australia and Canada). This process would have been a result of the increasing capitalization of agrarian activity which evidenced the "desire to change the environment" (Williams 1975, p. 87, for Australia) with the mechanization of production, the construction of irrigation systems and the progressively increasing use of fertilizers and special varieties of cereals. In brief, the option of the landowners could have been to intensify the use of production factors other than labour but our methodological approach is not capable to recognize this effect. 
Figure 12. Land frontier expansion according to intensive margin: acceptance of Ricardian process

Figure 12.a: Argentina

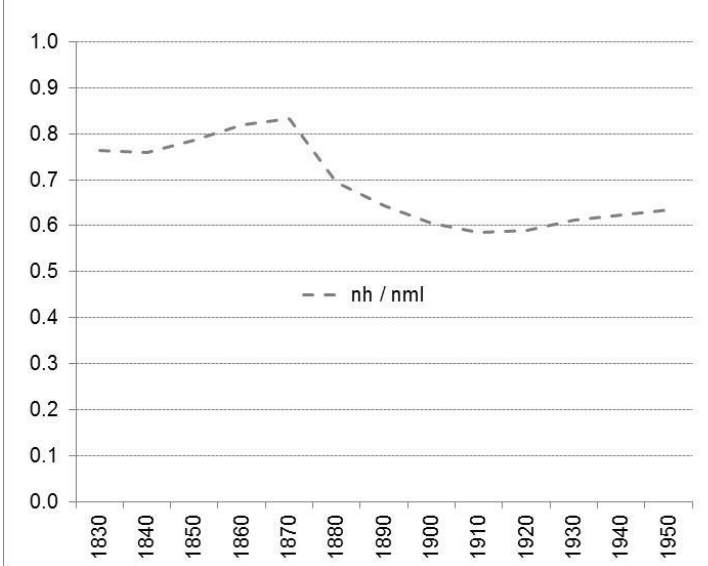

Figure 12.b: Chile

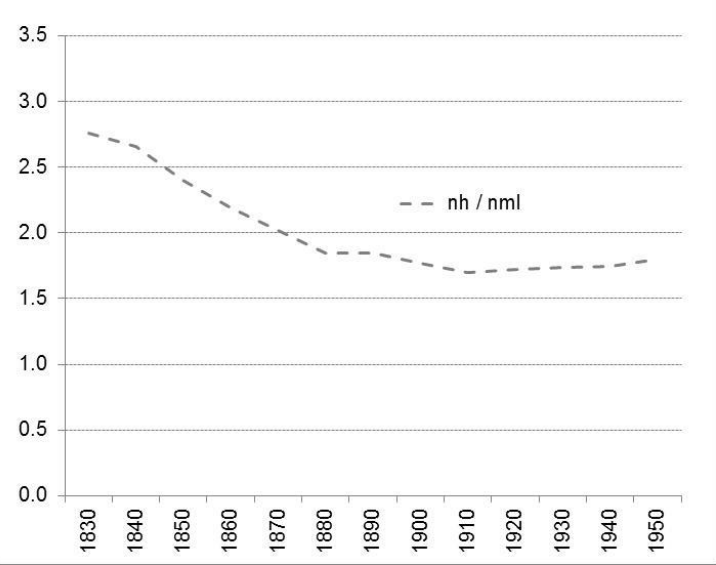

Figure 12.c: Uruguay

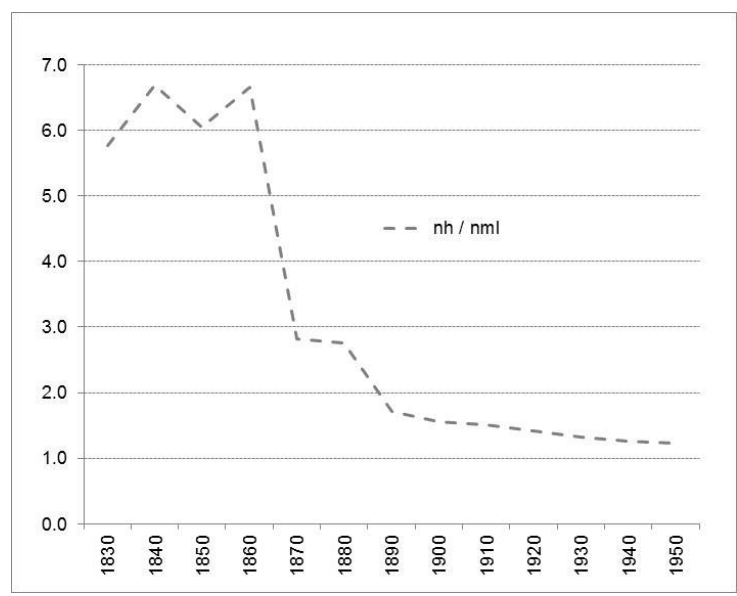




\section{Figure 13. Land frontier expansion according to intensive margin: rejection of Ricardian process}

Figure 13.a: Australia

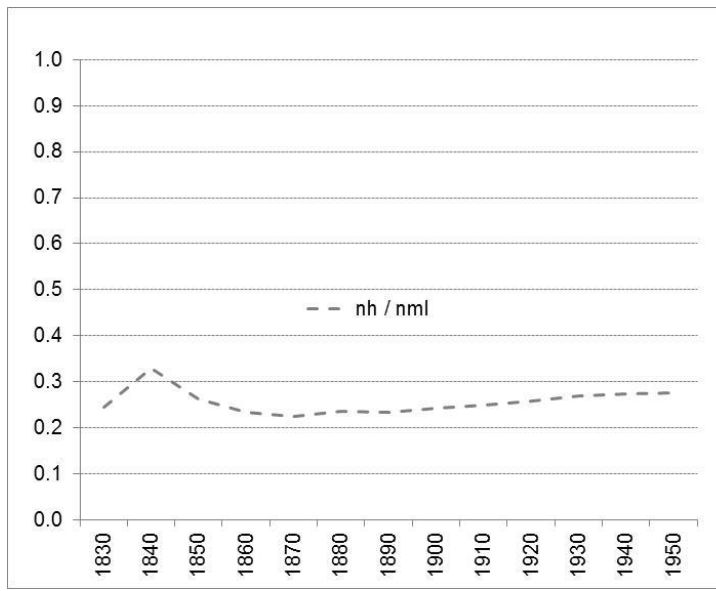

Figure 13.c: South Africa

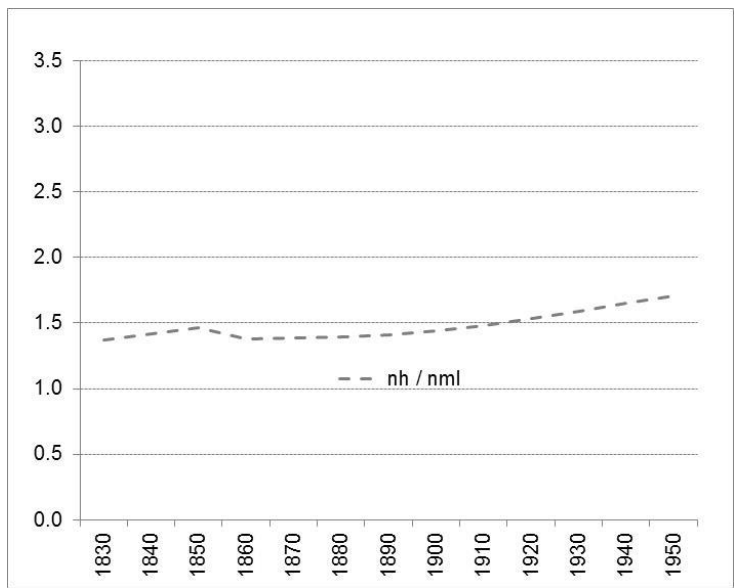

Figure 13.b: Canada

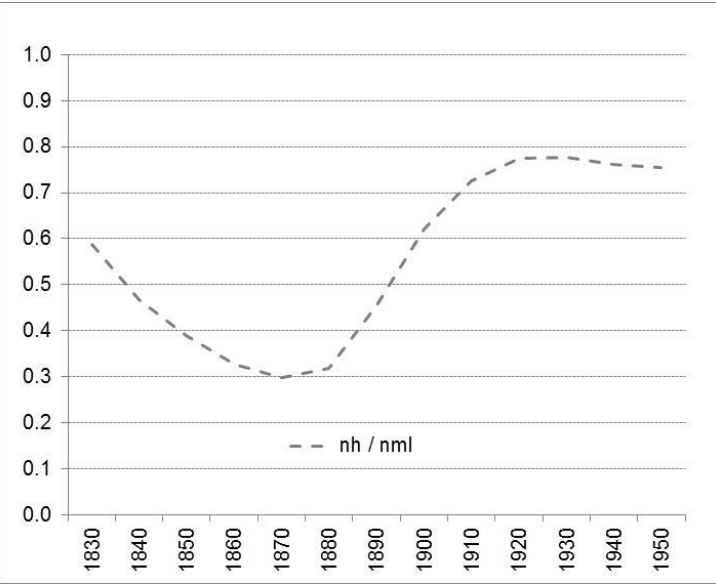

Figure 13.d: New Zealand

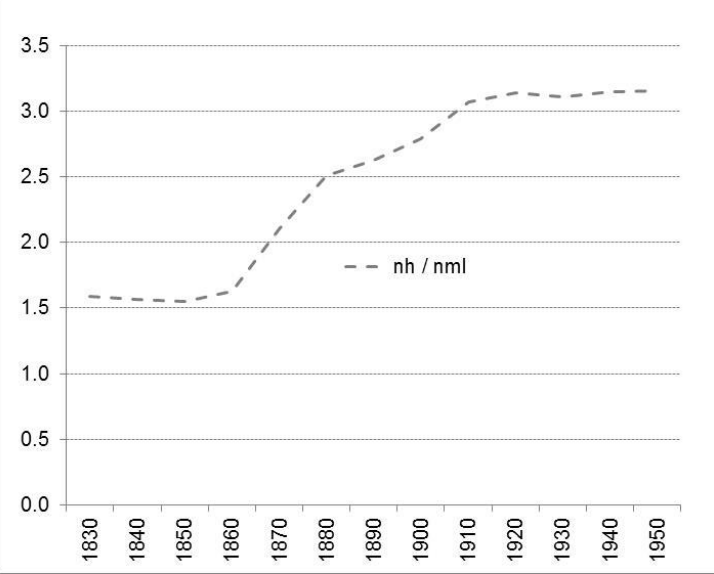

\section{Final comments and agenda}

By the late 19th century settler economies were well integrated into the global economy and achieved levels of income per capita on a par with the richest economies of the world. These economies benefited from the consequences of the Second Industrial Revolution as their natural endowments (temperate climate and fertile soils) were especially suitable for the production of food and raw materials. The abundance of natural resources was understood as a "blessing" as these countries were able to participate in external trade with resources that were up till then almost unexploited and for which European demand was dynamic and strong. 
The domestic contribution to economic growth was the incorporation of "new" land, of variable quality, into production, which had consequences on structural change, the evolution of income rates and the quantity and intensity of the use of production factors. We use the old notion of land frontier expansion which, in recent years, has reappeared following two paths -complementing and reacting to the mainstream- and offering new arguments to explain the comparative economic performance of settler economies during the First Globalization (from the 1870 s to, at least, the WWI) as a long-run process with roots in the previous period (1830-1870) and consequences in the following decades (until the WWII).

First, we present the concept of land frontier expansion in the recent theoretical and empirical analysis and discuss what the economic theory has proposed to understand the role of land in economic growth and income distribution. We decide on proposing an analytical model that considers the classical Ricardian view to understand the land frontier expansion in settler economies in terms of the extensive and intensive margins in the agrarian production.

We propose the use of GIS tools by considering different land agrarian aptitudes (we take into account 15 biomes and rank them in four categories: high, medium, low and not suitable for grassland) and distances to centres of gravity to test our hypotheses. We understand "quality" as the combination of aptitude to grassland and (minimum) distance to ports and large markets.

On the one hand, our evidence supports the extensive margin in the land frontier expansion of Argentina, Uruguay and New Zealand but reject it for Canada, Australia and Chile where the geographical and historical conditions seem to determine a different pattern. The evidence for South Africa is not conclusive and shows an intermediate situation. The location of initial settlements and the existence of mineral wealth in the territory are factors that transcend the Ricardian expectations and help to characterize more properly the process of land frontier expansion. On the other hand, our evidence does not support the intensive margin for Canada, Australia, New Zealand and South Africa but we do not reject this hypothesis for the Southern Cone of South America (Argentina, Chile and Uruguay). In other words, the reaction to the effects of First Globalization in these last economies meant the labour intensification in the use of the best lands while the other economies opted by other alternatives (for instance, the use of higher doses of capital). In brief, the land frontier expansion in Canada, Australia and South Africa does not fit with the Ricardian view of incorporation of "new" land in the agriculture and Argentina and Uruguay presented a process near to the Ricardian expectation. New Zealand shows a land frontier expansion clearly Ricardian in terms of the extensive margin, but the intensification of the use of land included factors different than labour. On the contrary, Chile did not expand the frontier in a Ricardian sense but increased the intensity of labour in the use of land in a typically rioplatense pattern.

Our agenda includes advancing in two directions. On the one hand, we propose to improve the characterization of the productive intensification process in the settler agricultures to answer the 
question: Was the capital or the labour that encouraged the agricultural production? In particular, the debate as to whether economic growth is profit-led or wage-led (Bhaduri 2008) seems an attractive question to analyze and has a bearing on the long-run performance of the "club" and the creation of "(post) staples economies" in the second half of the $20^{\text {th }}$ century (Wellstead 2007). One the other hand, our treatment of technology is excessively simplistic. Next steps in the research will look into this concept to evaluate the influence of the technological change on the land frontier expansion and, especially, how the extension of the railways facilitated the access to remote places. 


\section{Bibliography}

Aiton, A. (1940). "Latin-American Frontiers". Canadian Historical Association Report, pp. 100104. Reprinted in Weber, D. and Rausch, J. (1994) Where Cultures Meet. Frontiers in Latin American History. Jaguar Books on Latin America, No 6, Wilmington, Delaware, pp. 19-25.

Álvarez, J., Bilancini, E., D’Alessandro, S. and Porcile, G. (2011). "Agricultural Institutions, Industrialization and Growth: The Case of New Zealand and Uruguay in 1870-1940". Explorations in Economic History, Volume 48, Issue 2, April, pp. 151-168.

Álvarez, J and Willebald, H. (2013). "Agrarian income distribution, land ownership systems, and economic performance: settler economies during the First Globalization”. Documento de On Line $N^{\circ} 30$, Programa de Historia Económica y Social, Facultad de Ciencias Sociales (PHESFCS), Universidad de la República, Uruguay, Setiembre.

Arroyo Abad, L. (2013). "Persistent Inequality? Trade, Factor Endowments, and Inequality in Republican Latin America. The Journal of Economic History, Vol. 73, No. 1, March, pp. 3878.

Badía-Miró, M. (2008). "The Ports of Northern Chile: A Mining History in Long-run Perspective, 1880-2002". In Bergholm, T., Fischer, L.R. and Tonizzi, E. (ed). Making Global and Local Connections: Historical Perspectives on Ports en Research in Maritime History, No. 35 series.

Belaúnde V. (1923). "The Frontier in Hispanic America". Rice Institute pamphlets 10, October, pp. 202-213. Reprinted in Weber, D. and Rausch, J. (1994): Where Cultures Meet. Frontiers in Latin American History. Jaguar Books on Latin America, No 6, Wilmington, Delaware, pp. 33-41.

Bhaduri, A. (2008). "On the dynamics of profit-led and wage-led growth". Cambridge Journal of Economics, 32, pp. 147-160.

Bértola, L., Castelnovo, C., Rodríguez, J. and Willebald, H. (2010). "Between the Colonial Heritage and the First Globalization Boom: On Income Inequality in the Southern Cone". Revista de Historia Económica-Journal of Iberian and Latin American Economic History, Vol. 28, Issue 2/2010, Madrid, España, pp. 307-341.

Blaug, M. (1997). Economic Theory in Retrospect. Cambridge: Cambridge University Press.

Bolton, H. (1917). “The Mission as a Frontier Institution in the Spanish-American Colonies”. The American Historical Review, Vol. 23, No. 1, October, pp. 42-61.

Burt, A.L. (1965). "If Turner Had Looked at Canada, Australia, and New Zealand When He Wrote about the West". In Wyman, W. and Kroeber, C. (ed): The Frontier in Perspective. The University of Wisconsin Press, pp. 59-79.

Butland, G.J. (1966). "Frontiers of Settlement in South America”. Revista Geográfica, 65, pp. 93108.

Cao, H. y Rubins, R. (1996). Cuestión Regional y la Conformación del Estado-Nación en la Argentina. Instituto Nacional de la Administración Pública (INAP), $2^{\mathrm{a}}$ Edición, Buenos Aires, Argentina. 
Cariola, C. y Sunkel, O. (1982). La historia económica de Chile entre 1830 y 1930: dos ensayos y una bibliografía. Ed. Cultura Hispánica, Instituto de Cooperación Iberoamericana, Madrid.

Commonwealth Bureau of Census and Statistics (1910). Official Year Book of the Commonwealth of Australia. $\mathrm{N}^{\mathrm{O}} 3$, Melbourne, p. 669-677.

Coghlan, T.A. (1904). A statistical account of Australia and New Zealand, 1903-4. Sidney: W.A. Gullick, Government Printer.

Coleman, P. (1958). "The New Zealand Frontier and the Turner Thesis". Pacific Historical Review, Vol. 27, No. 3, August, pp. 221-237.

Crafts, N. (2005). "Market potential in British regions, 1871-1931". Regional Studies, 39 (9), pp.1159-1166.

Cross, M. (ed) (1970). The Frontier Thesis and the Canadas: The Debate on the Impact of the Canadian Environment. Toronto: Coop Clark.

Davis, R. (2006). "Introduction: transforming the frontier in contemporary Australia". Chapter 1. In Bird Rose, D. and Davis, R. (ed). Dislocating the frontier. Essaying the mystique of the outback. The Australian National University Press, pp. 7-22.

Duncan, T. and Fogarty, J. (1984). Australia and Argentina. On parallel paths. Melbourne University Press.

Findlay, R. (1995). Factor Proportions, Trade, and Growth. The MIT Press, Cambridge, Massachusetts, London, England. Chapter 5: “Trade, Migration, and the Moving Frontier”, pp. 121-145.

Findlay, R. and Lundahl, M. (2001). "Natural Resources and Economic Development: The 18701914 Experience”. In Auty, R. (Ed.): Resource Abundance and Economic Development. Oxford University Press, Oxford, pp. 95-112.

Findlay, R. and Lundahl, M. (1994). "Natural Resources, 'Vent-for-Surplus' and the Staples Theory". In Meier, G. (Ed.). From Classical Economics to Development Economics: Essays in Honor of Hla Myint. St. Martin's Press, New York, pp. 68-93.

Foreman-Peck, J. (1995). A history of the world economy: international economic relations since 1850. Harvester Wheatsheaf.

Francis, D. (1992). "The Frontier and Images of the Canadian West in the Settlement Era". Sophia University, $\quad$ http://repository.cc.sophia.ac.jp/dspace/bitstream/123456789/166/1/ 200000260873_000009000_19.pdf

Furniss, E. (2006). "Imagining the frontier: comparative perspectives from Canada and Australia". Chapter 2. In Bird Rose, D. and Davis, R. (eds). Dislocating the frontier. Essaying the mystique of the outback. The Australian National University Press, pp. 7-22.

García-Jimeno, C. and Robinson, J. (2011). "The Myth of the Frontier”. In Costa, D. and Lamoreaux, N. (ed). Understanding Long-Run Economic Growth: Geography, Institutions, and the Knowledge Economy. University of Chicago Press, pp. 49-88.

Harley, K. (2007). "Comments on factor prices and income distribution in less industrialized economies, 1870-1939: refocusing on the frontier". Australian Economic History Review, Vol. 47, No. 3, pp. 238-248, November.

Harris, C.D. (1954). "The market as a factor in the localization of industry in the United States". Annals of the Association of American Geographers, 44(4), pp. 315-348. 
Hartz, L. (1964). The Foundations of New Societies. Studies in the History of the United States, Latin America, South Africa, Canada, and Australia. Hartcourt, Brace \& World, Inc., New York.

Higham, C. and Thacker, R. (ed.) (2006). One West, Two Myths II. Essays on Comparison. University of Calgary Press.

Hubacek, K. and Van den Bergh, J. (2002). “The Role of Land in Economic Theory”. International Institute for Applied System Analysis (IIASA). Interim report. IR-02-037, pp. 1-48

Hurtado, C. (1966). Concentración de Población y Desarrollo Económico. El caso chileno. Instituto de Economía, Universidad de Chile.

Klein Goldewijk, K. and van Drecht, G. (2006). "HYDE 3: Current and historical population and land cover". In Bouwman, A.F., Kram, T. and Klein Goldewijk, K. (Ed.): Integrated modelling of global environmental change. An overview of IMAGE 2.4, pp. 93-111.

Klein Goldewijk, K., van Drecht, G. and Bouwman, A.F. (2007). "Mapping contemporary global cropland and grassland distributions on a $5 \times 5$ minute resolution". Journal of Land Use Science, 2:3, pp. 167-190.

Landes, D. (1998). The Wealth and the poverty of nations. New York: W.W. Norton.

Lewis, A. (1983). Crecimiento y fluctuaciones. Fundación de Cultura Económica, México.

Lloyd, Ch. and Metzer, J. (2013). "Settler Colonization and Societies in History: Patterns and Concepts”. In Lloyd, C., Metzer, J. and Sutch, R. (Eds.). Settler Economies in World History, Ch. 1, pp. 1-34.

Loveday, P. (1991). "Political History of the North". In Moffatt, I. and Webb, A. (eds). North Australian Research; Some Past Themes and New Directions, pp. 146-172, ANU, North Australia Research Unit, Darwin.

Martínez Galarraga, J. (2012). "The determinants of industrial location in Spain, 1856-1929". Explorations in Economic History, 49, pp. 255-275.

Mckinnon, M. (Ed.) (1997). New Zealand historical atlas. Auckland, NZ: David Bateman.

Mikesell, W. (1960). Comparative Studies in Frontier History”. Annals of the Association of American Geographers 50, March, pp. 62-74.

Moraes, M.I. (2008). La pradera perdida. Montevideo, Linardi y Risso.

Mukherjee, S. (2002). Modern Economic Theory. New Age International.

Nelson Institute for Environmental Studies. University of Wisconsin, Madison, http://www.sage.wisc.edu/atlas/, retrieved December 27, 2009.

Netherlands Environmental Assessment Agency (MNP), http://www.pbl.nl/en/themasites/hyde/index.html, retrieved December 27, 2009.

North, D. (2003). "The role of institutions in Economic Development". Discussion Paper Series, 2003.2, United Nations, October.

North, D., Summerhill, W. and Weingast, B. (2010). Violence and Social Orders. A conceptual Framework for Interpreting Recorded Human History. Cambridge University Press, New York.

North, D., Summerhill, W. and Weingast, B. (2000). "Order, Disorder and Economic Change: Latin America versus North America”. In Mesquita, B.B. d., and Root, H (Eds.) Governing for Prosperity, New Haven: Yale University Press. 
O'Rourke, K., Taylor, A. and Williamson J. (1996). "Factor Price Convergence in the Late Nineteenth Century”. International Economic Review, 37, pp. 499-530.

O’Rourke, K. and Williamson J. (1999). Globalization and History. Cambridge Mass: MIT Press.

O'Rourke, K. and Williamson J. (1994). "Late 19th Century Anglo-American Factor Price Convergence: Were Heckscher and Ohlin Right?”. Journal of Economic History, 54, 4, pp. 125 .

Ramankutty, N. and Foley, J. (1999). "Estimating historical changes in global land cover: Croplands from 1700 to 1992". Global Biogeochemical Cycles, Vol. 12, No. 4, December, pp. 997-1027.

Reynolds, H. (2003). The Law of the Land. Penguin Books (3ed edition).

Reynolds, H. (1987). Frontier: Aborigines, Settlers and Land. Allen and Unwin, Sidney.

Ricardo, D. (1821). On the Principles of Political Economy and Taxation. Library of Economics and Liberty. 2 October 2013. <http://www.econlib.org/library/Ricardo/ricP1a.html>.

Rosés, J. (2003). "Why isn't the whole of Spain industrialized? New Economic Geography and early industrialization, 1797-1910”. Journal of Economic History, 63(4), pp. 995-1022.

Sharp, P. (1955). "Three Frontiers: Some Comparative Studies of Canadian, American, and Australian Settlement”. Pacific Historical Review, November, pp. 369-377.

Statistics Canada (1915). The Canada Year Book 1914. Ottawa.

Statistics Canada (1914). The Canada Year Book 1913. Ottawa.

Schulze, M. (2007). "Regional income dispersion and market potential in the late nineteenth century Hapsburg Empire”. LSE Working Papers, No. 106/o7.

Slotkin, R. (1992). Gunfigther Nation: The Myth of the Frontier in the Twentieth Century America. Atheneum, New York.

Slotkin, R. (1985). The Fatal Environment: The Myth of the Frontier in the Age of Industrialization, 1800-1890. Atheneum, New York.

Tirado, D., Pons, J. and Paluzie, E. (2006). "Los cambios en la localización de la actividad industrial en España, 1850-1936. Un análisis desde la Nueva Geografía Económica”. Revista de Historia Industrial, 31, pp. 41-63

Turner, F.J. (1894). "The significance of the Frontier in American History”. Annual Report of the American Historical Association for 1893. Washington D.C. pp. 199-227. Reprinted in Turner, F.J. (1920). The Frontier in American History. New York: Henry Holt.

Turner J.R. (1912). "Henry C. Carey's Attitude toward the Ricardian Theory of Rent". The Quarterly Journal of Economics, Vol. 26, No. 4, Aug., pp. 644-672.

University of California, Museum of Paleontology. website, http://www.ucmp.berkeley.edu/ exhibits/biomes/index.php, retrieved December 27, 2009.

Walker, F. (1883). Land and its Rent. Boston: Little, Brown, and Company.

Weber, D. and Rausch, J. (1994). Where Cultures Meet. Frontiers in Latin American History. Jaguar Books on Latin America, No 6, Wilmington, Delaware.

Wellstead, A. (2007). "The (Post) Staples Economy and the (Post) Staples State in Historical Perspective". Canadian Political Science Review. Vol. 1 (1), pp. 8-25, June. 
Willebald, H. (2015). "Distributive patterns in settler economies: agrarian income inequality during the First Globalization (1870-1913)". Historia Agraria. Revista de agricultura e historia rural, 66, Agosto, pp. 75-104.

Willebald, H. (2013). "Are Institutions the Whole Story? Frontier Expansion, Land Quality and Ownership Rights in the River Plate, 1850-1920". In Hillbom E. and Svensson, P. (Eds). Agricultural Transformation in a Global History Perspective. Routledge Explorations in Economic History, February, Ch. 2, pp. 51-85.

Willebald, H. (2011). Natural resources, settler economies and economic development during the first globalization: land frontier expansion and institutional arrangement. $\mathrm{PhD}$ Thesis, Universidad Carlos III de Madrid, Departamento de Historia Económica e Instituciones, Archivo Abierto Institucional de la UC3M, Colecciones multidisciplinares, http://earchivo.uc3m.es/handle/10016/12281.

Willebald, H. (2007). "Desigualdad y especialización en el crecimiento de las economías templadas de nuevo asentamiento, 1870-1940". Revista de Historia Económica-Journal of Iberian and Latin American Economic History, 2/2007, pp. 291-345, Madrid, España.

Williams, M. (1975). "More and smaller is better: Australian rural settlement 1788-1914". In Powell, J.M. and Williams, M. (eds.). Australian space: Australian time. Oxford University Press, Melbourne, pp. 61-103.

Williamson, J. (2002). "Land, Labour and Globalization in the Third World, 1870-1940". Journal of Economic History. 62 (1), pp. 55-85, March.

Winks, R. (1981). "Australia, the Frontier, and the Tyranny of Distance". In Wolfskill, G. and Palmer, S. (eds). Essays on Frontiers in World History. pp. 121-146.

Winks, R. (1971). "The Myth of the American Frontier. Its relevance to America, Canada and Australia”. Sir George Watson Lecture, University of Leicester, 21 January.

Zavala, S. (1965). “The Frontier of Hispanic America”. In Wyman, W. and Kroeber, C. (ed). The Frontier in Perspective. The University of Wisconsin Press, pp. 35-58. 


\section{INSTITUTO DE ECONOMÍA}

\section{Serie Documentos de Trabajo}

Diciembre, 2016

DT $08 / 2016$

\section{i.econ}

Instituto de Economía

Facultad de Ciencias Económicas y de Administración

Universidad de la República - Uruguay

(C) 2011 iecon.ccee.edu.uy | instituto@iecon.ccee.edu.uy | Tel: +598 24000466 | +598 24001369 |+598 24004417 |Fax: +598 24089586 | Joaquín Requena 1375 | C.P. 11200 | Montevideo - Uruguay 